\title{
Progress in the quantity of financial information in the public sector in Mexico following the LGCG
}

\author{
Avances en la cantidad de información financiera del sector \\ público en México a raíz de la $L G C G$ \\ Laura Sour \\ Universidad Anahuac, Mexico
}

Received 4 February 2015; accepted 23 November 2015

Available online 21 March 2017

\begin{abstract}
This work evaluates the amount, quality, and harmonization of the financial information published by Mexico City, the states, and the Federal Government during the period of 2008-2012, following the approval of the General Law of Government Accounting (LGCG). Firstly, the requirements indicated by the CONAC and subsequently by the International Public Sector Accounting Standards (IPSAS) are used to evaluate the publication of financial statements. Secondly, the compliance of the publication of the accounts indicated by IPSAS 1, 2 and 17 is reported. Finally, the harmonization of the financial statements is studied through the Herfindahl-Hirschman Index (HHI) to determine if the financial statements are comparable with one another. The results indicate that the public sector has increased the amount, quality, and harmonization of the financial information published during the study period.

(C) 2017 Universidad Nacional Autónoma de México, Facultad de Contaduría y Administración. This is an open access article under the CC BY-NC-ND license (http://creativecommons.org/licenses/by-nc-nd/4.0/).
\end{abstract}

JEL classification: $\mathrm{H} 83 ; \mathrm{H} 76 ; \mathrm{M} 41$

Keywords: International Public Sector Accounting Standards (IPSAS); Public Sector Accounting; State government expenditure; Accountability; Mexico

\section{Resumen}

En este trabajo se evalúa la cantidad, calidad y armonización de la información financiera publicada por las entidades federativas, el Distrito Federal y el gobierno federal durante el periodo 2008-2012, a raíz de la aprobación de la Ley General de Contabilidad Gubernamental (LGCG). En primer lugar, se emplean los

E-mail addresses: laura.sour@anahuac.mx, laura.sour@gmail.com

Peer review under the responsibility of Universidad Nacional Autónoma de México. 
requerimientos señalados por el CONAC y, posteriormente, las Normas Internacionales de Contabilidad del Sector Público 1 (IPSAS por sus siglas en inglés) para evaluar la publicación de los estados financieros. En segundo lugar, se reporta el cumplimiento de la publicación de las cuentas que señalan los IPSAS 1, 2 y 17. Finalmente, se estudia la armonización de los estados financieros mediante el índice Herfindahl-Hirschman para determinar si los estados financieros son comparables entre sí. Los resultados apuntan a que el sector público ha aumentado la cantidad, calidad y la armonización de la información financiera publicada durante el periodo de estudio.

(C) 2017 Universidad Nacional Autónoma de México, Facultad de Contaduría y Administración. Este es un artículo Open Access bajo la licencia CC BY-NC-ND (http://creativecommons.org/licenses/by-nc-nd/4.0/).

Códigos JEL: $\mathrm{H} 83 ; \mathrm{H} 76 ; \mathrm{M} 41$

Palabras clave: Normas Internacionales de Contabilidad del Sector Público (NICS); Contabilidad gubernamental; Gasto público estatal; Rendición de cuentas; México

\section{Introduction}

In 2008, the approval of the General Law of Government Accounting (Ley General de Contabilidad Gubernamental - LGCG) opened a new path for the financial relation between Mexico City, the state governments, and the Federation in Mexico. This normativity proposes the creation of an accounting and financial information system in the public sector that is compatible at all three governmental levels. The general objective of this investigation is to testify to the progress achieved in this matter following the implementation of the LGCG up to 2012 in Mexico City, the states, and the federal government.

With this general objective in mind and considering the provisions implemented by the National Commission of Accounting Harmonization (Comisión Nacional de Armonización Contable CONAC), the first specific objective of this work is to review the presence or absence of a publication containing the financial statements of Mexico City, the states, and the Federal government, using the requirement indicated by the CONAC as reference. In addition to analyzing the progress at a national level, this work also seeks to determine if the path taken so far is relevant worldwide. Therefore, the publication of the financial statements is also reviewed based on the requirements that the International Federation of Accountants (IFAC) promotes through its International Public Sector Accounting Standards No. 1 (IPSAS).

The second specific objective is to analyze in detail the presence or absence of certain accounting elements in the financial reports recommended by IPSAS 1, 2 and 17. This second review is elaborated under the assumption that-if this is the information that the states, Mexico City, and the federal government are disseminating-it is proof that the quality to which public servants aspire seeks to comply with the best practices at an international level. This means that the IPSAS are the regulations that represent the best international practices in the elaboration of the financial statements. For this reason, if the state governments, Mexico City, and the Federal government are already generating their financial information according to these criteria, then it means that they are interested in creating an information system that is able to improve the monitoring of public resources. Thus, quality financial information improves the possibility of increasing our knowledge on the public policies implemented by public servants.

Finally, and in third place, the work shows the degree of progress in the harmonization of financial information of the federal government, Mexico City, and the states. Harmonization entails the publication of the same accounts or accounting elements at all government levels. For 
this, the Herfindahl-Hirschman Index (HHI) is used. This is a way to measure the degree in which the financial statements of each one of the states, Mexico City, and the federal government list the same items, so that they can be compared between each other during the period of 2008-2012.

The results of this study show that the LGCC has had an acceptable impact regarding the increase in the amount of financial statements published by the different government levels in the last couple of years. Similarly, advancements in the level of financial harmonization have also been found. In other words, since the promulgation of the LGCG, continuous efforts have been made for the generation of new harmonized governmental financial information, with accounting records that clearly portray the past, and which can be compared among different government levels throughout the years. If the accounting data are comparable, reproducible by third parties, sufficient and timely, then the government accounting will effectively help the financial evaluation of the results reached by public servants, and it will facilitate the projections required to feed the discussion on public policies that seek to improve social development.

The article is organized in the following manner. In the first section, the properties that the accounting information must comply with in the interest of being known for its quality at an international level are presented. In the second section, the methodology and the data used to elaborate this work is presented. The analysis of the financial information of Mexico City, the states, and the federal government is presented in the third section. The conclusions of this work are presented in the last section.

\section{Accounting government information properties at a national and international level}

From its most basic definition, accounting is a tool that generates the necessary quantifiable information to know the amount of resources that are used by the public servants in the production of goods and public services (Lara, Chávez, \& Toledo, 2011). Accounting can even reflect the efficiency in the management of public revenue, expenses, and government debt through an easy and transparent record system. Thus, all public reports are able to reveal the origin and allocation of every resource used in the management, and every input can be linked to its destination. Therefore, an efficient accounting system is able to present a correlation between the budget, public exercise and the results obtained in the three levels of government (Ferreira, 2012).

\section{The National Commission of Accounting Harmonization}

The National Commission of Accounting Harmonization (CONAC) came into existence along with the LGCG as an organization in charge of the coordination for the harmonization of government accounting. The CONAC brings together representatives of the states, the federal government, and the municipalities to indicate the minimal elements of the accounting manuals, to issue the classifiers of the accounting catalogs and accounting standards for the release of financial information, to generate the guidelines for the implementation of a cost system, to establish the methodological framework for the integration between the accounting records and the budget process, and to define the provisions for the accounting record of the public debt scheme. ${ }^{1}$

However, though it is important to analyze Mexico's case in light of the technical and legal criteria established by the CONAC, it is also important to estimate the progress achieved at an international level; even more so considering that one of the mandates of the CONAC is

\footnotetext{
1 Article 9 of the LGCG.
} 
to address the best accounting practices. Worldwide, the best practices to develop comparable information at the different government levels are IPSAS - issued by the International Federation of Accountants (IFAC). ${ }^{2}$ The IFAC was founded in 1977 with the purpose of establishing the values of integrity, transparency, and proficiency as the guiding principles of the accounting profession. The mission of the IFAC is to provide accounting guidelines for international use so that the financial statements of the public sector are able to acquire the necessary characteristics to be compared at an international level (Chan \& Zhang, 2013).

The IFAC establishes 32 IPSAS that comprise the accounting practices with the most international reliability for the structuring of quality financial information. These standards include guidelines for the presentation of financial information, such as cash flow statements, financial statements and investments, as well as for the government information of the assets, debt and financial instruments of the public sector (IFAC, 2013). Although the IFAC oversees the elaboration of the accounting standards for the public sector, this organization does not have the ability to enforce their use. However, IPSAS are followed by several countries (Galera \& Bolívar, 2011). Some Latin American examples are: Colombia, Costa Rica, Peru and Uruguay (Araya, Caba, \& López, 2011). In Europe, Spain chose to use IPSAS in 2010 because of a reform to the general public accounting plan to improve transparency and accountability toward its citizens (Brusca \& Montesinos, 2013). In the rest of the world, Australia, New Zealand, the United Kingdom and the United States have successfully integrated IPSAS to their accounting and financial information systems, as part of their modernization strategies for public management (Benito, Brusca, \& Montesinos, 2007; Fuertes, 2008). The experience of the countries that already use IPSAS show that the result is the innovation and the acknowledgment of good accounting and financial practices at an international level.

World organizations such as the International Monetary Fund (IMF), the World Bank (WB) and the United Nations Development Program, consider the adoption of IPSAS as a step toward modernization and government transparency (Chan \& Zhang, 2013). Therefore, IPSAS increase the reliability of financial information and promote data provision for accountability. Even the IMF is conditioning developing countries the release of new credits in exchange for the adoption of IPSAS by their authorities (Chan, 2008).

It is important to mention that one of the objectives of IPSAS is to achieve the harmonization of the accounting information, as is the case of financial statements, and even to reach the standardization of the accounting practices in the public sector between the different government levels in all countries. Because of these reasons, the observance of IPSAS is considered the first step taken by countries interested in starting a modernization process for their information systems (Fuertes, 2008). Developing countries are the ones that should more urgently incorporate IPSAS within their standards and accounting practices (Benito et al., 2007). Chan (2008) even lists the observance of IPSAS as an international benchmark to evaluate the government accounting practices and the accountability in accounting and financial matters.

\section{The possibilities of IPSAS to improve financial evaluation: some previous considerations}

IPSAS 1 and 2 establish the minimal requirements for the generation of both the content and the presentation of financial statements with the purpose of comparing and of having the conditions to make more informed decisions in financial matters in the public sector. It is known that the use

\footnotetext{
${ }^{2}$ IPSAS are issued by the International Public Sector Accounting Standards Board (IPSASB), an internal body of the IFAC.
} 
of the accrual record or the cash flow record has particular methodological implications. Thus, to compare the financial information between different entities it is necessary to use the same recording system, be it accrual or cash flow. Due to this, the governments must manifest the record system that they use, as the information generated with the accrual record is not comparable with that of the cash of flow record. Although the IPSASB acknowledges the right of the governments to establish accounting guidelines and standards for the presentation of their financial statements, it openly promotes the adoption of the accrual recording system as the best mechanism to obtain more precise information (Fuertes, 2008). ${ }^{3}$

For those governments that use the cash flow system, IPSAS 1 requests the full compliance of the provisions issued mainly to inform about this recording system. This is achieved through the publication of the collection and cash payment statement. In the presence of these omissions, the IFAC recommends using IPSAS 1, which corresponds to the accrual recording system, and voluntarily revealing in the "Financial statements notes" the accounting policies and the measurement bases used for the elaboration of the financial statements. The aforementioned is done so that the potential users of this information are able to correctly use these data and compare and analyze them against those of other governments (IFAC, 2013). Therefore, the financial information should always be carefully reviewed, as it could be assumed that the public servants have incorporated the accrual recording system into their routines and procedures, when in fact they have not.

To carry out a more complete financial evaluation, another important provision is IPSAS 17, the aim of which is the recognition and valuation of the fixed asset (IFAC, 2013). It is not hard to imagine that, appropriately accounting the needs of investment in a fixed asset, of the passive levels, or of the levels of public debt, shall improve the information about the value of public patrimony to implement public policies in the country. The analysis of three aspects of the Mexican government accounting system is below: the amount of data it generates, the quality of the same considering IPSAS; and the degree of harmonization reached during the analysis period.

\section{Methodology and data}

The first objective is to analyze the public accounts in the corresponding electronic portals of the state governments, Mexico City, and the Federal government to record the presence or absence of the 10 accounting information reports indicated by the CONAC in its Conceptual Framework for Government Accounting (Marco Conceptual de Contabilidad Gubernamental MCCG) during the period of 2008-2012. ${ }^{4}$ Subsequently, the presence or absence of the financial statements that IPSAS 1 indicates as a full set of financial statements for the public sector for the states, Mexico City, and the Federal government for each one of the years within the period of 2008-2012 is evaluated.

The second objective is to quantify the financial information published considering the requirements set by IPSAS 1,2, and 17 as an indicator of their quality, given that they represent the best

\footnotetext{
${ }^{3}$ Organizations that may have the intention of adopting the accrual accounting system in the future will find several publications of the IPSASB useful, especially Study 14 "Transition to the Accrual Accounting Basis: A guide for the Governments are Government Entities", where they will find a guide for the migration toward the accrual system (IFAC, 2007).

${ }^{4}$ Most of the database comes from the public accounts of Mexico City, the states, and the federal governments. However, a lot of the information was not found within these documents, thus it was necessary to visit the corresponding transparency portals. This absence of data is critical for the municipal case; thus that level of government is not included within the objectives of this investigation.
} 


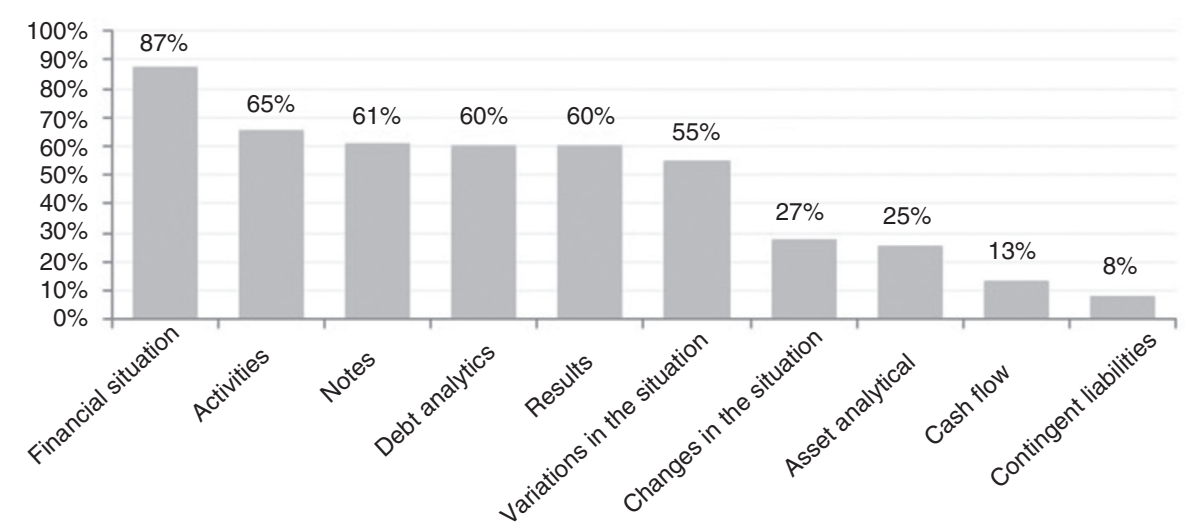

Figure 1. Publication percentages of accounting reports indicated by the CONAC (2008-2012). Source: Own elaboration with state and federal public accounts.

international practices in the elaboration of the financial statements of the public sector. In this manner, an assessment is made on whether the reports have the same information to build the financial reasons that facilitate the comparison of the state information with the information from the federal government and that of Mexico City.

The third objective is to calculate the level of harmonization of the accounts in the financial reports considering IPSAS 1 and 2, to see if the financial statements present the same accounts so that comparative assessments can be carried out between them.

\section{Analysis of the government accounting system in Mexico}

\section{Publication of the financial statements indicated by the CONAC (Consejo Nacional de Armonización Contable)}

Figure 1 indicates the frequency each one of the financial statements required by the CONAC (Consejo Nacional de Armonización Contable) is published during the analysis period. It can be observed that the statement of financial position is the most published (87\%), whereas the statement on contingent liabilities is the least published, followed by the cash flow statement. This information proves that the states present basic information regarding their assets, liabilities, and capital through the statement of financial position. However, they present insufficient reports regarding their obligations and the variations of assets, rights and their obligations.

\section{Publication of the financial statements indicated in International Public Sector Accounting Standard (IPSAS) 1}

IPSAS 1 defines a full set of financial statements as that which include the statement of financial position, income statement, statement of changes in the financial position, cash flow statement, and notes to the financial statements. It is worth mentioning that this documentation is included in the financial statements recommended by the CONAC.

In 2008, all states, including the federal government, published the income statement. The states of Mexico, Guanajuato, Querétaro, and Zacatecas were the states that published the most financial statements, reaching the maximum percentage observed in that year (75\%). ${ }^{5}$ In 2009 , with the

\footnotetext{
5 See Annex 1.
} 
implementation of the LGCG, an increase is observed regarding the publication of these financial statements when compared to the previous years: the average production of financial information at a national level increased 27 percentage points, reaching the highest average observed during the analysis period. Aguascalientes, Baja California Sur, Mexico City, Guanajuato, Jalisco, Morelos, Nayarit, Nuevo León, Oaxaca, Quintana Roo, Sonora, Tamaulipas, and Yucatán were the entities that released the most financial statements. Annex 2 presents the analysis of the publication of the financial statements by the states, in accordance with the requirements of IPSAS $1 .{ }^{6}$ The statement of financial position was published by all the states in 2009, except for Chihuahua and Guerrero (the latter did not present any type of accounting information in its internet website). For its part, Tlaxcala was the only state that generated its cash flow statement, an event that only occurred once during the entire analysis period.

In 2010 , the publication average of the financial statements analyzed decreased by $12 \%$. This downward trend was also observed in 2011-three years after the entry into force of the LGCG-when only 54\% of the financial statements analyzed that year were published. Aguascalientes, Baja California Sur, Mexico City, Morelos, Nayarit, Oaxaca, Querétaro, Sonora, and Yucatán were the states that published the most financial statements. Hidalgo-same as Guerrero-once again did not publish any financial statement, same as other states that did not comply, such as: Baja California, Durango and Sinaloa, who only presented one financial statement. The following year, an increase in the average of published financial statements can be observed, even though it is not very large (Annex 2).

The balance during the studied period is that Aguascalientes and Yucatán are the states with the largest amount of published financial statements required by IPSAS 1. Nayarit is one of the states that released the most financial statements in the last couple of years. The rest of the states present an inconsistent behavior. For example, among the states that published more statements at the beginning of the study is Querétaro, but in 2012 it only published one statement. During the analysis period Guerrero did not present any type of accounting information, and Chiapas and Tabasco are the states with the lowest percentage of compliance (20\%).

\section{Publication of the accounts indicated in IPSAS 1 and 2}

The accounts or items that are presented in each financial statement are reviewed based on the set of accounts that the IFAC establishes in IPSAS 1 to evaluate the financial development of the states. Thus, the analysis unit is the financial-accounting elements. The details of this section can be found in Annex 3. This means that the compliance of IPSAS 1 was evaluated through the presence or absence of the following elements in the financial statements: (a) The statement of financial position shows the lines of the current assets, cash, cash equivalents (Banks), inventories, accounts receivable from transactions with considerations (services), accounts receivable from transactions without considerations (taxes, fines), short-term credits, income from investments, noncurrent assets, properties, facilities and equipment, investment properties, land and buildings, short-term liabilities, long-term liabilities, public finance, retained earnings, reserves, period result; (b) In the income statement (or statement of financial performance) the accounts of the income, expense, financial costs, earnings or losses after taxes, and period result must be submitted; (c) In the notes, a summary is included regarding the accounting policies, such as measurement bases and

\footnotetext{
6 To quantify the presence, the value of 1 is used; and when the elements being searched are absent then the value of 0 is used. When the document is found but its content does not fully comply with the guidelines of IPSAS, a value of 0.5 is assigned to indicate that an element is incomplete.
} 
Table 1

States with the greatest-least capacity for the evaluation of the financial performance during the period of 2008-2012.

\begin{tabular}{|c|c|c|c|c|c|}
\hline Years & 2008 & 2009 & 2010 & 2011 & 2012 \\
\hline $\begin{array}{l}\text { States with the } \\
\text { greatest capacity }\end{array}$ & $\begin{array}{l}\text { Ags., Nay., } \\
\text { Federation } \\
(82 \%)^{\mathrm{a}}\end{array}$ & $\begin{array}{l}\text { D.F. }(91 \%) \text {, } \\
\text { Federation } \\
(86 \%)\end{array}$ & $\begin{array}{l}\text { Ags., Ver., } \\
\text { Federation } \\
(82 \%)\end{array}$ & $\begin{array}{l}\text { Ver. }(91 \%) \\
\text { B.C.S. }(89 \%)\end{array}$ & $\begin{array}{l}\text { Oax. }(86 \%) \text { B.C., } \\
\text { Gto., Mor., } \\
\text { Federation }(82 \%)\end{array}$ \\
\hline $\begin{array}{l}\text { States with the least } \\
\text { capacity }\end{array}$ & $\begin{array}{l}\text { Chih., Coah., } \\
\text { Tams. (13\%) }\end{array}$ & Chih. (17\%) & $\begin{array}{l}\text { Hgo. }(8 \%) \\
\text { Chih. }(13 \%)\end{array}$ & $\begin{array}{l}\text { B.C., Coah., } \\
\text { Hgo. }(13 \%)\end{array}$ & $\begin{array}{l}\text { Hgo. ( } 8 \%) \text {, Chih., } \\
\text { Coah. }(17 \%)\end{array}$ \\
\hline
\end{tabular}

Source: Own elaboration with public state and federal accounts.

a The percentages reflect the level of account publication for the evaluation of financial performance.

the upgrading of the fixed asset; (d) The state publishes a statement of changes in the net assets; and (e) The cash flow statement is included in the set of financial statements presented in the Account of public finance of each state. The elements of sections (a), (b), (c), and (d) enable the assessment of IPSAS 1, whereas the compliance of IPSAS 2 is determined by the report mentioned in section (e).

In accordance with Table 1, the states that publish more accounts and therefore have the best possibility to evaluate their financial performance, at least for one year of study, are: Aguascalientes, Mexico City, Veracruz, Baja California, Baja California Sur, Oaxaca, Morelos, Guanajuato, and the federal government. The aforementioned is due to the fact that they present an average above $80 \%$ in regard to the publication of accounts required by the IFAC. It can be observed that in 2009 , the information available in terms of assets at a national level increased with the help of Aguascalientes, Nayarit and the Federation, who published 90 percent of the elements requested. Eighty percent of the frequency of data related to the assets was published in Aguascalientes, Guanajuato, Morelos, Veracruz, and the Federation in 2010. In the following years, the percentage increased to 90 and was reached by Chiapas, Guanajuato, and Veracruz in the period of 2011, and only in the state of Oaxaca for 2012. It was the Federation and the state of Aguascalientes who published the most information regarding the assets in the study period.

Equity information by public entities is scarce: during the years analyzed, only in 2010 and 2011 did more than one state present these requirements in a complete manner. Aguascalientes, Durango, Puebla, Quintana Roo, San Luis Potosí, Sinaloa, Tamaulipas, Veracruz, Yucatán, Zacatecas, and the Federation are the ones that published the most information regarding public equities in 2010. The following year, this position was occupied by Baja California Sur, Chiapas, Colima, Durango, Guanajuato, Jalisco, Michoacán, Morelos, Querétaro, San Luis Potosi, Veracruz, and the Federation. The information presented is more substantial when the records of the liabilities are analyzed: most of the states publish information from these accounts, except for Chihuahua, Coahuila, Guerrero, Hidalgo, and Tlaxcala.

The activity report is evaluated with the accounts of the income statement, that is, the income and expenditure accounts, the financial costs, and the result of the financial year. The states of Zacatecas, Yucatán, and the Federation are the only ones that present all the accounts required to evaluate government activities. The rest of the states comply with $75 \%$ of the requirements.

It is important to remember that, for the information produced under the guidelines of IPSAS 1 to be comparable, it is necessary that the government specifies the recording basis of its accounting. In this manner, the financial statements done with an accrual recording basis could be comparable with other financial statements produced under the same accounting basis (IFAC, 2013). Thus, 
Table 2

Average percentages of the requirements of IPSAS 17.

\begin{tabular}{llllll}
\hline Years & 2008 & 2009 & 2010 & 2011 & 2012 \\
\hline Publication percentage & $47 \%$ & $65 \%$ & $66 \%$ & $66 \%$ & $68 \%$
\end{tabular}

Sources: Own elaboration with public state and federal accounts.

IPSAS 1 indicates the need to report - in the notes of the financial statements - the method used to evaluate the fixed asset and whether said evaluation has been updated, including their depreciation. The states of Oaxaca, Nuevo León, San Luis Potosí, Tabasco, Veracruz, and Yucatán publish information that enables the assessment of their quality and whether they can be compared with each other. Said statements provide information in regard to the update of the fixed asset and the measurement basis of their accounting statements during each one of the years after 2008. The rest of the states were not consistent with the presentation of this information.

\section{Publication of the accounts indicated in IPSAS 17}

IPSAS 17 establishes the minimum requirements to validate the recording of noncurrent assets of public entities, their depreciation (loss of value due to its use or over the course of time), as well as the measurement bases of the resources. ${ }^{7}$ This standard must be applied to all entities in the public sector that own properties, facilities, equipment - including those of a military nature - and the infrastructure asset. It is worth mentioning that IPSAS 17 does not require recording the historical, artistic or cultural heritages; however, should an entity fail to do so, it is recommended that it follows the guidelines established in this provision (IFAC, 2007).

Through IPSAS 17 it is possible to infer the comparability of the information published in the financial statements of the states, as the noncurrent assets comprise the resource that remains through time, and in a long-term period. The calculation of the real value of the resources is facilitated when depreciation is recorded. These records, along with the measurement basis, allow for the determination of whether the information is comparable when the same method is used to value these resources (González, 2011).

Before the year 2000, there is a great lack of information related to the noncurrent assets, investment properties, movable and immovable property, and the measurement basis with which these assets are assessed in each one of the studied government bodies (Annex 4). However, with the entry into force of the LGCG, the dissemination of this accounting information has considerably improved, going from a publication average of 47-68\% in 2012 (Table 2).

\section{Harmonization index in the accounts indicated in IPSAS 1 and 2}

Once the financial information requirements complied with by the states, Mexico City and the federal government have been analyzed, then the degree of financial harmonization can be evaluated to determine how comparable the data is between the bodies of the public sector that were studied throughout the course of time. For this purpose, the Herfindahl-Hirschman Index

\footnotetext{
7 The measurement bases approved for the recording of the assets in the financial statements are: historical cost, current cost, net realizable value, fair value or recoverable amount or recoverable service amount (IFAC, 2007).
} 
(HHI) is used. ${ }^{8}$ The information obtained from the HHI allows for the inference of the degree of uniformity of the data and thus, it is possible to conclude the level of accounting comparability in the country (Lara et al., 2011). The value of the HHI will vary between zero and one. When the publication of the data is concentrated in a few states, the HHI will take values closer to one. The HHI expression is the following:

$$
H=\sum_{i=1}^{k} p_{i}^{2}
$$

where $H$ is the HHI, $p$ indicates the number of elements that appear in the reviewed reports of each state $(i)$ that comply with IPSAS 1 and 2 with regard to the total criteria found at a national level, and variable $(k)$ is the number of states studied. Therefore, $p_{i}^{2}$ is the squared relative frequency of the elements of IPSAS 1 and 2 found in the sample (Rodríguez, 2009). Thus, based on the requirements of IPSAS 1 and 2, $\mathrm{H}$ indicates the concentration level with which the states publish their accounting information. ${ }^{9}$ The HHI indicates that the years with the highest accounting harmonization were 2009 and 2012, with a degree of harmonization of (0.03342560) and (0.03342658), respectively, as shown in Annex 5.

The highest value of HHI is observed in 2008 (0.03453), which means that in that year the comparability of the information was lower in comparison with the following years. This lack of harmonization can be explained by the fact that the guidelines of the LGCG were just emerging. The lowest harmonization or comparability in the financial information is observed in 2011, with an HHI of (0.03442). Fortunately, the HHI of 2011 does not reach that of 2008, which represents progress by itself.

A criteria to evaluate whether the changes were significant and therefore favorable throughout the years is to employ the concentration resolution mechanism of the Federal Economic Competition Commission (Comisión Federal de Competencia Económica), which states that if the change in the HHI is lower to (|0.02|), the changes that present themselves are not significant (Comisión Federal de Competencia, 1998).

Based on Table 3, it can be concluded that the marginal changes of the periods of 2008-2009 and 2011-2012 were superior to (|0.02I), and therefore the changes for a better accounting comparability are significant. The previous statement is consistent with the analysis presented up to this moment, in which it is declared that the years with the highest accounting harmonization were 2009 and 2012.

It can be concluded that the topic of financial harmonization at the different government levels in Mexico has obtained favorable results when compared to the year 2008, year in which the LGCG was not yet present. However, there is still room for improvement so that the harmonization of the accounting information is fully established in all states in the country.

\footnotetext{
8 The Herfindahl-Hirschman Index (HHI) is a statistical indicator commonly used to measure the level of concentration in an industry. The higher the index, the more concentrated the market and, therefore, there is less competition in the industry (Rhoades, 1993).

${ }^{9}$ The value of $\mathrm{H}$ depends on the number of entities analyzed in the sample ( 33 including the federal government). The minimum value of the HHI would be the maximum value of the frequency $(p)$ divided by the total number of states, that is $1 / 33=0.03030$. This value indicates that all the states have the same percentage of compliance regarding the international accounting standards. Therefore, a HHI close to 0.0330 indicates a significant harmonization level in the presentation of information (Sour, 2012).
} 
Table 3

Marginal changes in the HHI.

\begin{tabular}{llr}
\hline Year & HHI & Annual change \\
\hline 2008 & 0.034527329 & \\
2009 & 0.033425606 & -0.031908749 \\
2010 & 0.034161639 & 0.022020044 \\
2011 & 0.034424974 & 0.007708495 \\
2012 & 0.033426582 & -0.029001961 \\
\hline
\end{tabular}

Source: Own elaboration with data from state and federal accounts (2013).

Other advances on the road to improve the financial evaluation of the public sector in Mexico

The LGCG authorizes the National Commission of Accounting Harmonization (CONAC) to dictate the design and operation of the accounting system at a national level. The CONAC - comprised by representatives of the federation, the states and the municipalities - is in charge of designing the provisions that enable the compliance of the aspirations of the LGCG. The results show that the CONAC is keeping its promise to increase the amount of accounting and financial information of the Mexican government. They also show its concern to improve the quality of the information. Proof of this is that in 2009, it indicated the following financial statements as essential within the accounting information to be generated by the states: (i) Statement of financial position; (ii) Statement of activities (similar to the former Income Statement); (iii) Statement of changes in public finance/equity (formerly Statement of Changes in the Financial Position); (iv) Cash flow statement; and (v) Notes in the financial statements.

Furthermore, the manual, "Standards and Methodology for the Release of Financial Information and Structure of the Basic Financial Statements of the Public Entities and the characteristics of their notes" (Normas y Metodología para la Emisión de Información Financiera y Estructura de los Estados Financieros Básicos del Ente Público y características de sus notas), presents a format for the filling of the "Cash Flow Statement", the structure of which is consistent with the one recommended by IPSAS 2. The invitation of the CONAC for the generation of this report since 2010 is another improvement that promotes the release of information regarding the input and output flow of the resources of public administration. In 2012, according to article 9 of the LGCG, new recommendations were issued for the contents of the government account manuals, along with the re-classifiers of account catalogs; as well as the standards for accounting and for the release of financial information that have been formulated and proposed by the Technical Secretary of the CONAC.

The progress related to the unification of the depreciation system is also encouraging. The Secretariat of Finance and Public Credit issues standards-through its Government Accounting and Reports on Public Administration Unit (Unidad de Contabilidad Gubernamental e Informes sobre la Gestión Pública - UCGIGP)—to regulate its government accounting system. More specifically, it regulates anything related to use value, depreciation and re-evaluation, establishing the need to depreciate the tangible noncurrent assets of the public sector in order to carry out gradual economic projections to maintain and preserve public heritage. ${ }^{10}$ These institutional

\footnotetext{
10 The noncurrent tangible assets, defined within the Specific Standard for Government Financial Information (Norma Específica de Información Financiera Gubernamental - NEIFG 004VUDR, 2007:4,), are "the set of movable and immov-
} 
improvements are subject to the compliance on behalf of the states and to the agreement reached at a national level to define assets and national heritage. It is necessary for the states, led by the CONAC, to be willing to unify the depreciation evaluation system at the three government levels. Otherwise, the information will continue to not be comparable because, as previously explained, each state can make use of one of the accounting record methods to assess its assets (cash flow or accrual). The CONAC will also have to reconsider that the state governments inform the amounts of depreciation within the Financial Situation Statement of each one of the assets, as it is usually done in the private sector, instead of generally presenting it in the notes of the financial statements. This practice done in the private sector allows to more easily and specifically read the value of each one of the noncurrent assets, their accumulated depreciation and the net value once the same is subtracted. The hope is for these good practices to be complied with by the public sector and that their intention permeates the agreements that are promoted by the CONAC at a national level in regard to the valuation and depreciation of assets.

\section{Conclusions}

The information provided by government accounting constitutes the primary material for the realization of the financial evaluation of the public sector and to contribute to the discussion on the redesign of public policies. However, for this to happen, the government accounting needs to comply with certain suitability criteria to ensure their veracity, reliance and opportunity. These attributes enable the connection between the internal administration of the government and the administration of public policies in Mexico. Thus, in that moment the production of quality information shall allow the "culture of evaluation" to grow in the country.

The LGCG aims to achieve a kind of harmonization that reviews, re-structures and seeks to make compatible the current accounting elements at a national level. This action will produce information that will be available in the interest of enriching the discussion on the quality of the expenses in the country. This is an advantage of the LGCG that has not been highlighted and that becomes relevant in light of the not so favorable outlook on public finances. The lack of available resources forces civil servants and citizens to discuss, now having more information, how the resources will be assigned to obtain the greatest benefit possible. In this sense, the technical role of the CONAC to produce quality data is important, but even more so is their political behavior to encourage all government levels to join in the effort to reach the objectives of the LGCG as soon as possible. There is evidence that the sum of all these efforts has made the publication of financial information in the country more prosperous.

Several countries-both developed and developing-are adopting the new government accounting model, based on the recommendations proposed by the IFAC in terms of the generation, report, and publication of their accounting information through IPSAS. The progress made in this subject indicates that the matter is moving in the right direction, given that in 2009 and 2012 several states published all the financial statements requested by the CONAC and IPSAS 1. This is the first objective of the work. The years with the most financial publications were 2009 and 2012. Aguascalientes and Yucatán stand out as the states with the most publications through the analyzed period.

The second objective entails the evaluation of the financial information of the states analyzed using as parameters IPSAS 1, 2, and 17 as an approximation to analyze quality in light of the

able property that can be appreciated through the senses, that is, it is material, for example: land, buildings, machinery, tools, etc." (UCGIGP, 2008). 
accounts required at an international level. Several states published more than 80 percent of the accounts required. The states that have a greater viability to carry out a financial evaluation, at least for one of the study years, are: Aguascalientes, Mexico City, Veracruz, Baja California, Baja California Sur, Oaxaca, Morelos, Guanajuato, and the Federal Government. It is worth mentioning that the liabilities portion of the states is better known than that of the equities.

Oaxaca, Nuevo León, San Luis Potosí, Veracruz, Tabasco and Michoacán are the states with a good performance and quality regarding their accounting information, and which comply with all the requirements to carry out a financial evaluation. These states serve as models to those that have yet to release consistent asset updates or measurement bases reports of the financial statements.

There is little information available before 2009 on the asset register, depreciation and the accounting measurement basis. However, based on the analysis of IPSAS 17, it can be observed that since the entry into force of the LGCG, there is a growing tendency in the publication of these data at a national level. The LGCG does not establish the obligation to do the valuation and depreciation corresponding to the fixed asset, nor does it mention the method of depreciation or the rate that will apply. This void is a wake-up call for the CONAC to bring this matter up for discussion with the governors, who are in charge of the conciliation of the political wills. This is a discussion that should start at a local level.

The discussion on the adoption of an accrual record system that enables a better understanding of the assets and the availability of public resources should also start at this level. In this manner, there is the possibility to better evaluate the present, but also to generate more accurate estimates regarding longer term tendencies. Only with the reliable construction of the goals reached-and of all that remains to be done-will it be possible to imagine a different future for Mexico.

The third objective was to use the HHI to evaluate the degree of harmonization of the information in the financial statements based on the criteria indicated in IPSAS 1 and 2. Based on the results obtained, it is concluded that there is a greater accounting standardization going from 2008 to 2012, even though the full participation of the states is still not there. The foregoing is consistent with the results obtained in a survey carried out by the Technical Secretariat of the CONAC and the National Association of Superior Controlling Authorities and Government Control (Asociación Nacional de Organismos de Fiscalización Superior y Control Gubernamental - ASOFIS) for the state organizations of accounting harmonization. The progress done in terms of accounting harmonization on behalf of the states has been favorable, but the objectives and efforts to fully comply with the requirements of the LGCG remain in effect so that the accounting systems of the public sector at the three government levels are in complete harmony (CONAC, 2013).

The highest level of harmonization can be observed in 2012, which could be explained by the amount of time that the LGCG had been in force, as the length of time since its promulgation had been sufficient for the states to be presenting their financial reports according to the law. Another possible explanation is that in this year, the CONAC provided the state entities with an electronic tool called Sig@if which allows automating some accounting processes such as the administration of income, outcome, account plan, and the catalog of suppliers and beneficiaries. ${ }^{11}$ This was done for those states that did not have an automated accounting tool (CONAC, 2013). ${ }^{12}$

\footnotetext{
${ }^{11}$ Harmonized Government System of Financial Information (Sistema Gubernamental Armonizado de Información Financiera - Sig@if), "application developed by the CONAC, with the objective of providing all public entities with a tool and the necessary services to achieve the goals of accounting harmonization" (CONAC, 2012).

12 Automated accounting tool: It is the tool that automatically records in real time the registers of the accounting and budget operations (Asociación Nacional de Organismos de Fiscalización Superior y Control Gubernamental, 2012).
} 
The LGCG authorizes the CONAC to dictate the way in which the accounting system must be designed and operated. The CONAC is in charge of making the agreements, at a national level, that will fill the key gaps in the institutional framework. The experts indicate that the culture, conservatism, and special characteristics of the government have an influence in the way in which the accounting model in each country is defined, but at the same time, they state that a greater political competition forges the efficient performance of the government and the increase in transparency and accountability. For this virtuous circle to be completed it is also necessary that the elaboration of the study on the quality of the expenses in Mexico increases to enrich the democratic and plural debate in the country, this in the interest of developing the social welfare of the population. The information system promoted by LGCG seeks to build the necessary elements to evaluate the financial capacity of the public sector. These actions will help improve the practices for the evaluation of the expenses, and will not only improve the evaluation, but also the discussion on public policies to promote social development and the economic growth of the country.

\section{Appendix A.}

Annex 1

Financial statements published in accordance with the CONAC (Annual percentages).

\begin{tabular}{lrrrrr}
\hline Years & 2008 & 2009 & 2010 & 2011 & 2012 \\
\hline Minimum publication percentage & $25 \%$ & $25 \%$ & $25 \%$ & $0 \%$ & $0 \%$ \\
Average of publications released from the required total & $55 \%$ & $70 \%$ & $62 \%$ & $54 \%$ & $57 \%$ \\
Maximum publication percentage & $75 \%$ & $100 \%$ & $75 \%$ & $75 \%$ & $100 \%$ \\
\hline
\end{tabular}

Source: Own elaboration with state and federal public accounts. 
Annex 2

Financial statements published in accordance with IPSAS 1 (2008-2012).

\begin{tabular}{|c|c|c|c|c|c|c|c|c|c|c|c|c|c|c|c|c|c|c|c|c|c|c|c|c|c|c|c|c|c|c|}
\hline \multirow[t]{2}{*}{ State } & \multicolumn{5}{|c|}{$\begin{array}{l}\text { Statement of financial } \\
\text { position }\end{array}$} & \multicolumn{5}{|c|}{ Income statement } & \multicolumn{5}{|c|}{$\begin{array}{l}\text { Statement of changes } \\
\text { in the financial } \\
\text { position }\end{array}$} & \multicolumn{5}{|c|}{ Cash flow statement } & \multicolumn{5}{|c|}{ Notes } & \multicolumn{5}{|c|}{ Total } \\
\hline & 2008 & 2009 & 2010 & 2011 & 2012 & 2008 & 2009 & 2010 & 2011 & 2012 & 2008 & 2009 & 2010 & 2011 & 2012 & 2008 & 2009 & 2010 & 2011 & 2012 & 2008 & 2009 & 2010 & 2011 & 2012 & 2008 & 2009 & 2010 & 2011 & 2012 \\
\hline Fed & $\sqrt{ }$ & $\sqrt{ }$ & $\sqrt{ }$ & $\sqrt{ }$ & $\sqrt{ }$ & $\sqrt{ }$ & x & $\sqrt{ }$ & $x$ & $x$ & $\sqrt{ }$ & $x$ & $x$ & $x$ & $x$ & $x$ & $x$ & $x$ & $x$ & $\sqrt{ }$ & $\times$ & $\sqrt{ }$ & $\sqrt{ }$ & $\sqrt{ }$ & $\sqrt{ }$ & 3 & 2 & 3 & 2 & 3 \\
\hline Ags & $\sqrt{ }$ & $\sqrt{ }$ & $\sqrt{ }$ & $\sqrt{ }$ & $\sqrt{ }$ & $\sqrt{ }$ & $\sqrt{ }$ & $\sqrt{ }$ & $\sqrt{ }$ & $\sqrt{ }$ & $\sqrt{ }$ & $\sqrt{ }$ & $\sqrt{ }$ & $\sqrt{ }$ & $\sqrt{ }$ & $\times$ & $x$ & $x$ & $x$ & $x$ & $\times$ & $\sqrt{ }$ & $\sqrt{ }$ & $\sqrt{ }$ & $\sqrt{ }$ & 3 & 4 & 4 & 4 & 4 \\
\hline $\mathrm{BC}$ & $\sqrt{ }$ & $\sqrt{ }$ & $\sqrt{ }$ & $x$ & $\sqrt{ }$ & $\sqrt{ }$ & $\sqrt{ }$ & $\sqrt{ }$ & $\sqrt{ }$ & $x$ & $\sqrt{ }$ & $x$ & $\sqrt{ }$ & $x$ & $x$ & $x$ & $x$ & $x$ & $x$ & $\sqrt{ }$ & $x$ & $x$ & $\sqrt{ }$ & $x$ & $\sqrt{ }$ & 3 & 2 & 4 & 1 & 3 \\
\hline $\mathrm{BCS}$ & $\sqrt{ }$ & $\sqrt{ }$ & $\sqrt{ }$ & $\sqrt{ }$ & $\sqrt{ }$ & $\sqrt{ }$ & $\sqrt{ }$ & $\sqrt{ }$ & $\sqrt{ }$ & $\sqrt{ }$ & $\sqrt{ }$ & $\sqrt{ }$ & $\sqrt{ }$ & $\sqrt{ }$ & $\sqrt{ }$ & $x$ & $x$ & $\times$ & $x$ & $\sqrt{ }$ & $x$ & $x$ & $\sqrt{ }$ & $\sqrt{ }$ & $x$ & 3 & 3 & 4 & 4 & 4 \\
\hline Camp & $\sqrt{ }$ & $\sqrt{ }$ & $\sqrt{ }$ & $\sqrt{ }$ & $\sqrt{ }$ & $\sqrt{ }$ & $\sqrt{ }$ & $x$ & $\times$ & $\times$ & $x$ & $\sqrt{ }$ & $x$ & $\sqrt{ }$ & $\times$ & $x$ & $x$ & $\sqrt{ }$ & $\sqrt{ }$ & $\sqrt{ }$ & $\times$ & $\sqrt{ }$ & $\times$ & $\sqrt{ }$ & $\sqrt{ }$ & 2 & 4 & 2 & 3 & 3 \\
\hline Chis & $\times$ & $\sqrt{ }$ & $\sqrt{ }$ & $\sqrt{ }$ & $\sqrt{ }$ & $\sqrt{ }$ & $\sqrt{ }$ & $\sqrt{ }$ & $\times$ & $\times$ & $\sqrt{ }$ & $\sqrt{ }$ & $x$ & $x$ & $\times$ & $x$ & $x$ & $\times$ & $\times$ & $x$ & $\sqrt{ }$ & $\sqrt{ }$ & $\times$ & $\sqrt{ }$ & $x$ & 3 & 4 & 2 & 2 & 1 \\
\hline Chih & $x$ & $x$ & $x$ & $x$ & $x$ & $\sqrt{ }$ & $\sqrt{ }$ & $\sqrt{ }$ & $\sqrt{ }$ & $\sqrt{ }$ & $\sqrt{ }$ & $\sqrt{ }$ & $\sqrt{ }$ & $\sqrt{ }$ & $\sqrt{ }$ & $x$ & $x$ & $x$ & $x$ & $x$ & $\theta$ & $x$ & $\sqrt{ }$ & $\sqrt{ }$ & $\sqrt{ }$ & 3 & 2 & 3 & 3 & 3 \\
\hline Coah & $\sqrt{ }$ & $\sqrt{ }$ & $\sqrt{ }$ & $\times$ & $\times$ & $\sqrt{ }$ & $\sqrt{ }$ & $\sqrt{ }$ & $\sqrt{ }$ & $\sqrt{ }$ & $\sqrt{ }$ & $\sqrt{ }$ & $x$ & $x$ & $x$ & $x$ & $x$ & $\sqrt{ }$ & $x$ & $x$ & $x$ & $x$ & $x$ & $\sqrt{ }$ & $\sqrt{ }$ & 3 & 3 & 3 & 2 & 2 \\
\hline Col & $\sqrt{ }$ & $\sqrt{ }$ & $\sqrt{ }$ & $\sqrt{ }$ & $\sqrt{ }$ & $\sqrt{ }$ & $\sqrt{ }$ & $\sqrt{ }$ & $\sqrt{ }$ & $\sqrt{ }$ & $\sqrt{ }$ & $\sqrt{ }$ & $\sqrt{ }$ & $\sqrt{ }$ & $\times$ & $x$ & $x$ & $x$ & $x$ & $x$ & $x$ & $x$ & $x$ & $x$ & $x$ & 3 & 3 & 3 & 3 & 2 \\
\hline DF & $\sqrt{ }$ & $\sqrt{ }$ & $\sqrt{ }$ & $\sqrt{ }$ & $\sqrt{ }$ & $\sqrt{ }$ & $\sqrt{ }$ & $\sqrt{ }$ & $\sqrt{ }$ & $\sqrt{ }$ & $x$ & $\sqrt{ }$ & $\sqrt{ }$ & $\sqrt{ }$ & $\sqrt{ }$ & $x$ & $x$ & $x$ & $x$ & $x$ & $\times$ & $\sqrt{ }$ & $\sqrt{ }$ & $\sqrt{ }$ & $\sqrt{ }$ & 2 & 4 & 4 & 4 & 4 \\
\hline Dgo & $\sqrt{ }$ & $\sqrt{ }$ & $\sqrt{ }$ & $\sqrt{ }$ & $\sqrt{ }$ & $\sqrt{ }$ & $\sqrt{ }$ & $x$ & $x$ & $x$ & $\theta$ & $\sqrt{ }$ & $\sqrt{ }$ & $x$ & $x$ & $x$ & $x$ & $x$ & $x$ & $x$ & $\sqrt{ }$ & $x$ & $\sqrt{ }$ & $x$ & $\theta$ & 4 & 3 & 3 & 1 & 2 \\
\hline Mex & $\sqrt{ }$ & $\sqrt{ }$ & $\sqrt{ }$ & $\sqrt{ }$ & $\theta$ & $\sqrt{ }$ & $\sqrt{ }$ & $\sqrt{ }$ & $x$ & $\theta$ & $\sqrt{ }$ & $\sqrt{ }$ & $\sqrt{ }$ & $\sqrt{ }$ & $\sqrt{ }$ & $x$ & $x$ & $x$ & $x$ & $x$ & $\sqrt{ }$ & $\sqrt{ }$ & $\sqrt{ }$ & $x$ & $\sqrt{ }$ & 4 & 4 & 4 & 2 & 3 \\
\hline Gto & $x$ & $\sqrt{ }$ & $\sqrt{ }$ & $\sqrt{ }$ & $\sqrt{ }$ & $\sqrt{ }$ & $\sqrt{ }$ & $\sqrt{ }$ & $x$ & $x$ & $x$ & $\sqrt{ }$ & $\sqrt{ }$ & $x$ & $\sqrt{ }$ & $x$ & $x$ & $x$ & $x$ & $\sqrt{ }$ & $x$ & $\sqrt{ }$ & $\sqrt{ }$ & $\sqrt{ }$ & $\sqrt{ }$ & 1 & 4 & 4 & 2 & 4 \\
\hline Gro & $x$ & $*$ & $*$ & $*$ & $*$ & $\sqrt{ }$ & $*$ & $*$ & $*$ & $*$ & $\sqrt{ }$ & $*$ & $*$ & $*$ & $*$ & $x$ & $*$ & $*$ & $*$ & * & $x$ & $*$ & $*$ & $*$ & * & 1 & * & $*$ & 0 & 0 \\
\hline Hgo & $\sqrt{ }$ & $\sqrt{ }$ & $x$ & $x$ & $x$ & $\sqrt{ }$ & $\sqrt{ }$ & $\sqrt{ }$ & $x$ & $x$ & $\sqrt{ }$ & $\sqrt{ }$ & $x$ & $x$ & $x$ & $x$ & $x$ & $x$ & $x$ & $x$ & $x$ & $\sqrt{ }$ & $x$ & $x$ & $x$ & 3 & 4 & 1 & 0 & 0 \\
\hline Jal & $x$ & $\sqrt{ }$ & $\sqrt{ }$ & $\sqrt{ }$ & $\sqrt{ }$ & $\sqrt{ }$ & $\sqrt{ }$ & $\sqrt{ }$ & $\sqrt{ }$ & $\sqrt{ }$ & $x$ & $\sqrt{ }$ & $x$ & $\sqrt{ }$ & $x$ & $x$ & $x$ & $x$ & $x$ & $x$ & $x$ & $\sqrt{ }$ & $x$ & $x$ & $\sqrt{ }$ & 2 & 4 & 2 & 3 & 3 \\
\hline Mich & $\sqrt{ }$ & $\sqrt{ }$ & $\sqrt{ }$ & $\sqrt{ }$ & $\sqrt{ }$ & $\sqrt{ }$ & $x$ & $x$ & $\times$ & $\times$ & $\sqrt{ }$ & $\sqrt{ }$ & $x$ & $x$ & $x$ & $x$ & $x$ & $x$ & $x$ & $x$ & $x$ & $\sqrt{ }$ & $\sqrt{ }$ & $\sqrt{ }$ & $\sqrt{ }$ & 3 & 3 & 2 & 2 & 2 \\
\hline Mor & $\sqrt{ }$ & $\sqrt{ }$ & $\sqrt{ }$ & $\sqrt{ }$ & $\sqrt{ }$ & $\sqrt{ }$ & $\sqrt{ }$ & $\sqrt{ }$ & $\sqrt{ }$ & $x$ & $\sqrt{ }$ & $\sqrt{ }$ & $\sqrt{ }$ & $\sqrt{ }$ & $x$ & $x$ & $x$ & $x$ & $\times$ & $\sqrt{ }$ & $x$ & $\sqrt{ }$ & $\sqrt{ }$ & $\sqrt{ }$ & $\sqrt{ }$ & 3 & 4 & 4 & 4 & 3 \\
\hline Nay & $\sqrt{ }$ & $\sqrt{ }$ & $\sqrt{ }$ & $\sqrt{ }$ & $\sqrt{ }$ & $\sqrt{ }$ & $\sqrt{ }$ & $\sqrt{ }$ & $\sqrt{ }$ & $\sqrt{ }$ & $x$ & $\sqrt{ }$ & $x$ & $x$ & $\sqrt{ }$ & $x$ & $x$ & $\sqrt{ }$ & $\sqrt{ }$ & $\sqrt{ }$ & $\sqrt{ }$ & $\sqrt{ }$ & $\sqrt{ }$ & $\sqrt{ }$ & $\sqrt{ }$ & 3 & 4 & 4 & 4 & 5 \\
\hline NL & $\sqrt{ }$ & $\sqrt{ }$ & $\sqrt{ }$ & $\sqrt{ }$ & $\sqrt{ }$ & $\sqrt{ }$ & $\sqrt{ }$ & $\sqrt{ }$ & $\times$ & $x$ & $\sqrt{ }$ & $\sqrt{ }$ & $x$ & $x$ & $\times$ & $x$ & $x$ & $\sqrt{ }$ & $\sqrt{ }$ & $\sqrt{ }$ & $x$ & $\sqrt{ }$ & $\sqrt{ }$ & $\sqrt{ }$ & $\sqrt{ }$ & 3 & 4 & 4 & 3 & 3 \\
\hline Oax & $\sqrt{ }$ & $\sqrt{ }$ & $\sqrt{ }$ & $\sqrt{ }$ & $\sqrt{ }$ & $\sqrt{ }$ & $\sqrt{ }$ & $x$ & $\sqrt{ }$ & $\times$ & $\sqrt{ }$ & $\sqrt{ }$ & $\sqrt{ }$ & $\sqrt{ }$ & $\sqrt{ }$ & $\times$ & $x$ & $x$ & $x$ & $\times$ & $\times$ & $\sqrt{ }$ & $\sqrt{ }$ & $\sqrt{ }$ & $\sqrt{ }$ & 3 & 4 & 3 & 4 & 3 \\
\hline Pue & $\sqrt{ }$ & $\sqrt{ }$ & $\sqrt{ }$ & $\sqrt{ }$ & $\sqrt{ }$ & $\sqrt{ }$ & $\sqrt{ }$ & $\sqrt{ }$ & $\sqrt{ }$ & $\sqrt{ }$ & $x$ & $\sqrt{ }$ & $x$ & $x$ & $x$ & $x$ & $x$ & $x$ & $x$ & $x$ & $x$ & $\sqrt{ }$ & $\sqrt{ }$ & $\sqrt{ }$ & $\sqrt{ }$ & 2 & 4 & 3 & 3 & 3 \\
\hline Qro & $\sqrt{ }$ & $\sqrt{ }$ & $\sqrt{ }$ & $\sqrt{ }$ & $\sqrt{ }$ & $\sqrt{ }$ & $x$ & $\sqrt{ }$ & $\sqrt{ }$ & $\times$ & $\sqrt{ }$ & $\sqrt{ }$ & $\sqrt{ }$ & $\sqrt{ }$ & $x$ & $x$ & $x$ & $x$ & $x$ & $x$ & $\sqrt{ }$ & $\sqrt{ }$ & $\sqrt{ }$ & $\sqrt{ }$ & $x$ & 4 & 3 & 4 & 4 & 1 \\
\hline QRoo & $\sqrt{ }$ & $\sqrt{ }$ & $\sqrt{ }$ & $\sqrt{ }$ & $\sqrt{ }$ & $\sqrt{ }$ & $\sqrt{ }$ & $\sqrt{ }$ & $x$ & $x$ & $\sqrt{ }$ & $\sqrt{ }$ & $\sqrt{ }$ & $x$ & $x$ & $\times$ & $x$ & $x$ & $\sqrt{ }$ & $\sqrt{ }$ & $x$ & $\sqrt{ }$ & $\sqrt{ }$ & $\sqrt{ }$ & $\sqrt{ }$ & 3 & 4 & 4 & 3 & 3 \\
\hline SLP & $\sqrt{ }$ & $\sqrt{ }$ & $\sqrt{ }$ & $\sqrt{ }$ & $\sqrt{ }$ & $\sqrt{ }$ & $\sqrt{ }$ & $\sqrt{ }$ & $x$ & $x$ & $x$ & $\sqrt{ }$ & $x$ & $x$ & $x$ & $x$ & $x$ & $x$ & $x$ & $x$ & $x$ & $\sqrt{ }$ & $\sqrt{ }$ & $\sqrt{ }$ & $\sqrt{ }$ & 2 & 4 & 3 & 2 & 2 \\
\hline $\operatorname{Sin}$ & $\sqrt{ }$ & $\sqrt{ }$ & $\sqrt{ }$ & $\sqrt{ }$ & $\sqrt{ }$ & $\sqrt{ }$ & $\times$ & $x$ & $x$ & $\times$ & $\sqrt{ }$ & $\sqrt{ }$ & $\sqrt{ }$ & $x$ & $\sqrt{ }$ & $x$ & $x$ & $x$ & $x$ & $\sqrt{ }$ & $x$ & $x$ & $x$ & x & $\sqrt{ }$ & 3 & 2 & 2 & 1 & 4 \\
\hline Son & $\sqrt{ }$ & $\sqrt{ }$ & $\sqrt{ }$ & $\sqrt{ }$ & $\sqrt{ }$ & $\sqrt{ }$ & $\sqrt{ }$ & $\sqrt{ }$ & $\sqrt{ }$ & $\sqrt{ }$ & $\sqrt{ }$ & $\sqrt{ }$ & $\sqrt{ }$ & $\sqrt{ }$ & $\sqrt{ }$ & $x$ & $x$ & $x$ & $x$ & $x$ & $x$ & $\sqrt{ }$ & $x$ & $\sqrt{ }$ & $\sqrt{ }$ & 3 & 4 & 3 & 4 & 4 \\
\hline Tab & $x$ & $\sqrt{ }$ & $\sqrt{ }$ & $\sqrt{ }$ & $\sqrt{ }$ & $\sqrt{ }$ & $\sqrt{ }$ & $\sqrt{ }$ & $\sqrt{ }$ & $x$ & $x$ & $\sqrt{ }$ & $x$ & $x$ & $x$ & $x$ & $x$ & $x$ & $x$ & $x$ & $x$ & $\sqrt{ }$ & $\sqrt{ }$ & $\sqrt{ }$ & $x$ & 1 & 4 & 3 & 3 & 1 \\
\hline Tams & $\sqrt{ }$ & $\sqrt{ }$ & $\sqrt{ }$ & $\sqrt{ }$ & $\sqrt{ }$ & $\sqrt{ }$ & $\sqrt{ }$ & $\sqrt{ }$ & $\sqrt{ }$ & $\sqrt{ }$ & $x$ & $\sqrt{ }$ & $x$ & $x$ & $\sqrt{ }$ & $x$ & $x$ & $x$ & $x$ & $x$ & $x$ & $\sqrt{ }$ & $\sqrt{ }$ & $\sqrt{ }$ & $\sqrt{ }$ & 2 & 4 & 3 & 3 & 4 \\
\hline Tlax & $\sqrt{ }$ & $\sqrt{ }$ & $*$ & $\sqrt{ }$ & $\sqrt{ }$ & $\sqrt{ }$ & $\sqrt{ }$ & $*$ & $\sqrt{ }$ & $\sqrt{ }$ & $\sqrt{ }$ & $\sqrt{ }$ & $*$ & $x$ & $\sqrt{ }$ & $x$ & $\sqrt{ }$ & * & $x$ & $x$ & $\times$ & $x$ & $*$ & $x$ & $\times$ & 3 & 4 & $*$ & 2 & 3 \\
\hline Ver & $\sqrt{ }$ & $\sqrt{ }$ & $\sqrt{ }$ & $\sqrt{ }$ & $\theta$ & $\sqrt{ }$ & $\sqrt{ }$ & $x$ & $x$ & $\theta$ & $\sqrt{ }$ & $x$ & $x$ & $x$ & $x$ & $x$ & $x$ & $x$ & $x$ & $\sqrt{ }$ & $x$ & $\sqrt{ }$ & $\sqrt{ }$ & $\sqrt{ }$ & $\sqrt{ }$ & 3 & 3 & 2 & 2 & 3 \\
\hline Yuc & $\sqrt{ }$ & $\sqrt{ }$ & $\sqrt{ }$ & $\sqrt{ }$ & $\sqrt{ }$ & $\sqrt{ }$ & $\sqrt{ }$ & $\sqrt{ }$ & $\sqrt{ }$ & $x$ & $\sqrt{ }$ & $\sqrt{ }$ & $\sqrt{ }$ & $x$ & $\sqrt{ }$ & $x$ & $x$ & $x$ & $\sqrt{ }$ & $\sqrt{ }$ & $x$ & $\sqrt{ }$ & $\sqrt{ }$ & $\sqrt{ }$ & $\sqrt{ }$ & 3 & 4 & 4 & 4 & 4 \\
\hline $\mathrm{Zac}$ & $\sqrt{ }$ & $\sqrt{ }$ & $\sqrt{ }$ & $\sqrt{ }$ & $\sqrt{ }$ & $\sqrt{ }$ & $\sqrt{ }$ & $\sqrt{ }$ & $\sqrt{ }$ & $x$ & $\sqrt{ }$ & $x$ & $x$ & $x$ & $x$ & $x$ & $x$ & $x$ & $x$ & $\sqrt{ }$ & $\sqrt{ }$ & $\sqrt{ }$ & $x$ & $x$ & $\sqrt{ }$ & 4 & 3 & 2 & 2 & 3 \\
\hline Total & 29 & 31 & 29 & 28 & 28 & 24 & 28 & 25 & 19 & 13 & 33 & 28 & 16 & 11 & 13 & 0 & 1 & 4 & 5 & 13 & 6.5 & 24 & 22 & 23 & 25 & 92 & 112 & 96 & 86 & 92 \\
\hline
\end{tabular}

Source: Own elaboration with federal and state public accounts. 
Annex 3

Public accounts in accordance with IPSAS 1 and 2 (2008-2012).

\begin{tabular}{|c|c|c|c|c|c|c|c|c|c|c|c|}
\hline \multirow[t]{2}{*}{ Financial statement } & \multirow[t]{2}{*}{ Item } & \multicolumn{5}{|c|}{ States } & \multicolumn{5}{|c|}{ Federation } \\
\hline & & 2008 & 2009 & 2010 & 2011 & 2012 & 2008 & 2009 & 2010 & 2011 & 2012 \\
\hline \multirow{18}{*}{$\begin{array}{l}\text { Statement of financial } \\
\text { position or General Balance }\end{array}$} & Current Asset & 26 & 30 & 27 & 27 & 28 & $\sqrt{ }$ & $\sqrt{ }$ & $\sqrt{ }$ & $\sqrt{ }$ & $\sqrt{ }$ \\
\hline & Cash & 19 & 19 & 18 & 21 & 24 & $\times$ & $\sqrt{ }$ & $\sqrt{ }$ & $\sqrt{ }$ & $\sqrt{ }$ \\
\hline & Cash equivalent (Banks) & 19 & 26 & 23 & 22 & 27 & $\sqrt{ }$ & $\sqrt{ }$ & $\sqrt{ }$ & $\sqrt{ }$ & $\sqrt{ }$ \\
\hline & Inventories & 9 & 8 & 7 & 7 & 9 & $\sqrt{ }$ & $\sqrt{ }$ & $\sqrt{ }$ & $\sqrt{ }$ & $\sqrt{ }$ \\
\hline & $\begin{array}{l}\text { Accounts receivable from } \\
\text { transactions with considerations } \\
\text { (services) }\end{array}$ & 3 & 13 & 12 & 13 & 0.5 & $\times$ & $\times$ & $x$ & $\sqrt{ }$ & $x$ \\
\hline & $\begin{array}{l}\text { Accounts receivable from } \\
\text { transactions without considerations } \\
\text { (taxes, transfers) }\end{array}$ & 3 & 8 & 8 & 8.5 & 3.5 & $\sqrt{ }$ & $\sqrt{ }$ & $\sqrt{ }$ & $\times$ & $\times$ \\
\hline & Short-term credits & 23 & 24 & 25 & 25 & 27 & $\sqrt{ }$ & $\sqrt{ }$ & $\sqrt{ }$ & $\sqrt{ }$ & $\sqrt{ }$ \\
\hline & Income from investments & 16 & 18 & 20 & 18 & 23 & $\sqrt{ }$ & $\sqrt{ }$ & $\times$ & $x$ & $\sqrt{ }$ \\
\hline & Noncurrent asset & 24 & 30 & 28 & 27 & 28 & $\sqrt{ }$ & $\sqrt{ }$ & $\sqrt{ }$ & $\sqrt{ }$ & $\sqrt{ }$ \\
\hline & Properties, facilities, and equipment & 26.5 & 26 & 27 & 25 & 28 & $\sqrt{ }$ & $\sqrt{ }$ & $\sqrt{ }$ & $\sqrt{ }$ & $\sqrt{ }$ \\
\hline & Investment properties & 8 & 9 & 12 & 14 & 22 & $\sqrt{ }$ & $\sqrt{ }$ & $\sqrt{ }$ & $\sqrt{ }$ & $\sqrt{ }$ \\
\hline & Land and buildings & 25.5 & 26 & 26 & 24 & 28 & $\sqrt{ }$ & $\sqrt{ }$ & $\sqrt{ }$ & $\sqrt{ }$ & $\sqrt{ }$ \\
\hline & Short-term liability & 26 & 30 & 28 & 26 & 28 & $\sqrt{ }$ & $\sqrt{ }$ & $\sqrt{ }$ & $\sqrt{ }$ & $\sqrt{ }$ \\
\hline & Long-term liability & 22 & 29 & 28 & 26 & 27 & $\sqrt{ }$ & $\sqrt{ }$ & $\sqrt{ }$ & $\sqrt{ }$ & $\sqrt{ }$ \\
\hline & Public Finance & 24 & 25 & 26 & 27 & 28 & $\sqrt{ }$ & $\sqrt{ }$ & $\sqrt{ }$ & $\sqrt{ }$ & $\sqrt{ }$ \\
\hline & Retained profits & $*$ & $*$ & $*$ & $*$ & $*$ & $*$ & $*$ & $*$ & $*$ & $*$ \\
\hline & Reserves & 2 & 1 & 11 & 11 & 1 & $x$ & $x$ & $\sqrt{ }$ & $\sqrt{ }$ & $\times$ \\
\hline & Results & 23 & 29 & 28 & 27 & 27 & $\sqrt{ }$ & $\sqrt{ }$ & $\sqrt{ }$ & $\sqrt{ }$ & $\sqrt{ }$ \\
\hline \multirow{5}{*}{ Income statement } & Income & 31 & 31 & 28 & 31 & 31 & $\sqrt{ }$ & $\sqrt{ }$ & $\sqrt{ }$ & $\sqrt{ }$ & $\sqrt{ }$ \\
\hline & Expenses & 31 & 31 & 28 & 31 & 31 & $\sqrt{ }$ & $\sqrt{ }$ & $\sqrt{ }$ & $\sqrt{ }$ & $\sqrt{ }$ \\
\hline & Financial costs & 15 & 6 & 8 & 9 & 25 & $\sqrt{ }$ & $\sqrt{ }$ & $x$ & $\sqrt{ }$ & $\sqrt{ }$ \\
\hline & Earnings or losses before taxes & 2 & 3 & 0 & 4 & 0 & $\sqrt{ }$ & $\sqrt{ }$ & $\times$ & $\times$ & $x$ \\
\hline & Result & 30 & 31 & 27 & 30 & 30 & $\sqrt{ }$ & $\sqrt{ }$ & $\sqrt{ }$ & $\sqrt{ }$ & $\sqrt{ }$ \\
\hline \multirow{2}{*}{ Notes } & Measurement bases & 3.5 & 13 & 15 & 17 & 14 & $\sqrt{ }$ & $\times$ & $\times$ & $x$ & $\times$ \\
\hline & Update of the fixed asset & 1 & 26 & 19 & 20 & 7 & $x$ & $\times$ & $\times$ & $x$ & $x$ \\
\hline
\end{tabular}


Annex 4

Accounts published in accordance with IPSAS 17 (2008-2012).

\begin{tabular}{|c|c|c|c|c|c|c|c|c|c|c|c|c|c|c|c|c|c|c|c|c|c|c|c|c|c|c|c|c|c|c|c|c|c|c|c|}
\hline \multirow[t]{2}{*}{ State } & \multicolumn{5}{|c|}{ Noncurrent Asset } & \multicolumn{5}{|c|}{ Properties, equipment } & \multicolumn{5}{|c|}{ Investment properties } & \multicolumn{5}{|c|}{ Land and buildings } & \multicolumn{5}{|c|}{ Measurement bases } & \multicolumn{5}{|c|}{ Update fixed asset } & \multicolumn{5}{|c|}{ Percentage } \\
\hline & 2008 & 2009 & 2010 & 2011 & 2012 & 2008 & 2009 & 2010 & 2011 & 2012 & 2008 & 2009 & 2010 & 2011 & 2012 & 2008 & 2009 & 2010 & 2011 & 2012 & 2008 & 2009 & 2010 & 2011 & 2012 & 2008 & 2009 & 2010 & 2011 & 2012 & 2008 & 2009 & 2010 & 2011 & 2012 \\
\hline Fed & $\sqrt{ }$ & $\sqrt{ }$ & $\sqrt{ }$ & $\sqrt{ }$ & $\sqrt{ }$ & $\sqrt{ }$ & $\sqrt{ }$ & $\sqrt{ }$ & $\sqrt{ }$ & $\sqrt{ }$ & $\sqrt{ }$ & $\sqrt{ }$ & $\sqrt{ }$ & $\sqrt{ }$ & $\sqrt{ }$ & $\sqrt{ }$ & $x$ & $\sqrt{ }$ & $\sqrt{ }$ & $\sqrt{ }$ & $\sqrt{ }$ & $x$ & $x$ & $x$ & $x$ & $x$ & $\sqrt{ }$ & $x$ & $x$ & $x$ & 0.8 & 0.7 & 0.7 & 0.7 & 0.7 \\
\hline & $\sqrt{ }$ & $\sqrt{ }$ & $\sqrt{ }$ & $\sqrt{ }$ & $\sqrt{ }$ & $\sqrt{ }$ & $\sqrt{ }$ & $\sqrt{ }$ & $\sqrt{ }$ & $\sqrt{ }$ & & $\sqrt{ }$ & $x$ & $x$ & $\sqrt{ }$ & $\sqrt{ }$ & $\sqrt{ }$ & $\sqrt{ }$ & $\sqrt{ }$ & $\sqrt{ }$ & $x$ & $x$ & $\sqrt{ }$ & $\sqrt{ }$ & $x$ & $x$ & $\sqrt{ }$ & $\sqrt{ }$ & $\sqrt{ }$ & $x$ & 0.5 & 0.8 & 0.8 & 0.8 & 0.8 \\
\hline BC & $\sqrt{ }$ & $\sqrt{ }$ & $\sqrt{ }$ & $x$ & $\sqrt{ }$ & $\sqrt{ }$ & $\sqrt{ }$ & $\sqrt{ }$ & $x$ & $\sqrt{ }$ & $x$ & $x$ & $\sqrt{ }$ & $x$ & $\sqrt{ }$ & $\sqrt{ }$ & $\sqrt{ }$ & $\sqrt{ }$ & $\times$ & $\sqrt{ }$ & $x$ & $x$ & $x$ & $x$ & $\sqrt{ }$ & $x$ & $x$ & $\sqrt{ }$ & $x$ & $\sqrt{ }$ & 0.5 & 0.5 & 0.8 & 0.0 & 0.0 \\
\hline BCS & $\sqrt{ }$ & $\sqrt{ }$ & $\sqrt{ }$ & $\sqrt{ }$ & $\sqrt{ }$ & $\sqrt{ }$ & $\sqrt{ }$ & $\sqrt{ }$ & $\sqrt{ }$ & $\sqrt{ }$ & $x$ & $\sqrt{ }$ & $x$ & $\sqrt{ }$ & $x$ & $\sqrt{ }$ & $\sqrt{ }$ & $\sqrt{ }$ & $\theta$ & $\sqrt{ }$ & $x$ & $x$ & $\sqrt{ }$ & $\sqrt{ }$ & $x$ & $\times$ & $\times$ & $\sqrt{ }$ & $\sqrt{ }$ & $x$ & 0.5 & 0.7 & 0.8 & 0.9 & 0.9 \\
\hline amp & $\sqrt{ }$ & $\sqrt{ }$ & $\sqrt{ }$ & $\sqrt{ }$ & $\sqrt{ }$ & $\sqrt{ }$ & $\sqrt{ }$ & $\sqrt{ }$ & $\sqrt{ }$ & $\sqrt{ }$ & $x$ & $\sqrt{ }$ & $\sqrt{ }$ & $\sqrt{ }$ & $\sqrt{ }$ & $x$ & $\sqrt{ }$ & $x$ & $x$ & $\sqrt{ }$ & $x$ & $x$ & $x$ & $x$ & $x$ & $x$ & $\sqrt{ }$ & $x$ & $\sqrt{ }$ & $x$ & 0.2 & 0.8 & 0.5 & 0.7 & 0.7 \\
\hline & $\sqrt{ }$ & $\sqrt{ }$ & $\sqrt{ }$ & $\sqrt{ }$ & $\sqrt{ }$ & $\sqrt{ }$ & $\sqrt{ }$ & $\sqrt{ }$ & $\sqrt{ }$ & $\sqrt{ }$ & $v$ & $x$ & $x$ & $\sqrt{ }$ & $\sqrt{ }$ & $\sqrt{ }$ & $\sqrt{ }$ & $\sqrt{ }$ & $\sqrt{ }$ & $\sqrt{ }$ & $x$ & & $x$ & $\sqrt{ }$ & $x$ & $x$ & $x$ & $x$ & $\sqrt{ }$ & $x$ & 0.7 & .5 & .5 & 1.0 & 1.0 \\
\hline Chih & $x$ & $x$ & $x$ & $x$ & $x$ & $x$ & $x$ & $\times$ & $x$ & $x$ & $x$ & $\times$ & $x$ & 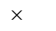 & $x$ & $x$ & $x$ & $x$ & $x$ & $x$ & $\sqrt{ }$ & 상 & $\sqrt{ }$ & $\sqrt{ }$ & $\sqrt{ }$ & $x$ & $\sqrt{ }$ & $\sqrt{ }$ & $\sqrt{ }$ & x & 0.2 & 0.2 & 0.3 & 0.3 & 0.3 \\
\hline Coah & $x$ & $\sqrt{ }$ & $\sqrt{ }$ & $x$ & $x$ & $\times$ & $\sqrt{ }$ & $\sqrt{ }$ & $x$ & $x$ & $x$ & $x$ & $x$ & $x$ & $x$ & $x$ & $\sqrt{ }$ & $\sqrt{ }$ & $x$ & $x$ & $\theta$ & $x$ & $x$ & $\sqrt{ }$ & $\sqrt{ }$ & $x$ & $\sqrt{ }$ & $x$ & $x$ & $x$ & 0.1 & 0.7 & 0.5 & 0.2 & 0.2 \\
\hline & $\sqrt{ }$ & $\sqrt{ }$ & $\sqrt{ }$ & $\sqrt{ }$ & $\sqrt{ }$ & $\sqrt{ }$ & $\sqrt{ }$ & $\sqrt{ }$ & $\sqrt{ }$ & $\sqrt{ }$ & & $x$ & $\sqrt{ }$ & $\sqrt{ }$ & $\sqrt{ }$ & $\sqrt{ }$ & $\sqrt{ }$ & $\sqrt{ }$ & $\sqrt{ }$ & $\sqrt{ }$ & $x$ & $x$ & $\times$ & $x$ & $x$ & $x$ & $\sqrt{ }$ & $\times$ & & $x$ & .5 & 0.7 & .7 & 17 & 0.7 \\
\hline & $\sqrt{ }$ & $\sqrt{ }$ & $\sqrt{ }$ & $\sqrt{ }$ & $\sqrt{ }$ & $\sqrt{ }$ & $\sqrt{ }$ & $\sqrt{ }$ & $\sqrt{ }$ & $\sqrt{ }$ & $\sqrt{ }$ & $\sqrt{ }$ & $\sqrt{ }$ & $\sqrt{ }$ & $x$ & $\sqrt{ }$ & $\sqrt{ }$ & $\sqrt{ }$ & $\sqrt{ }$ & $\sqrt{ }$ & $x$ & $x$ & $x$ & $x$ & $x$ & $x$ & $\sqrt{ }$ & $\sqrt{ }$ & $\sqrt{ }$ & $x$ & 0.7 & 0.8 & 0.8 & 0.8 & 0.8 \\
\hline$g_{0}$ & $\sqrt{ }$ & $\sqrt{ }$ & $\sqrt{ }$ & $\sqrt{ }$ & $\sqrt{ }$ & $\sqrt{ }$ & $\sqrt{ }$ & $\sqrt{ }$ & $\sqrt{ }$ & $\sqrt{ }$ & $x$ & $x$ & $x$ & $x$ & $x$ & $\sqrt{ }$ & $\sqrt{ }$ & $\sqrt{ }$ & $\sqrt{ }$ & $\sqrt{ }$ & $x$ & $x$ & $x$ & $x$ & $x$ & $x$ & $x$ & $x$ & $x$ & $x$ & 0.5 & 0.5 & 0.5 & 0.5 & 0.5 \\
\hline$e x$ & $\sqrt{ }$ & $\sqrt{ }$ & $\sqrt{ }$ & $\sqrt{ }$ & $\sqrt{ }$ & $\sqrt{ }$ & $\sqrt{ }$ & $\sqrt{ }$ & $\sqrt{ }$ & $\sqrt{ }$ & 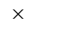 & $x$ & x & & $\sqrt{ }$ & $\sqrt{ }$ & $\sqrt{ }$ & $\sqrt{ }$ & $\sqrt{ }$ & $\sqrt{ }$ & $\sqrt{ }$ & $\sqrt{ }$ & $\times$ & & $\sqrt{ }$ & X & $x$ & $\sqrt{ }$ & $x$ & $\sqrt{ }$ & 0.7 & 0.7 & ).7 & 0.5 & 0.5 \\
\hline जto & $\sqrt{ }$ & $\sqrt{ }$ & $\sqrt{ }$ & $\sqrt{ }$ & $\sqrt{ }$ & $\sqrt{ }$ & $\sqrt{ }$ & $\sqrt{ }$ & $\sqrt{ }$ & $\sqrt{ }$ & $x$ & $\sqrt{ }$ & $x$ & $\sqrt{ }$ & $\sqrt{ }$ & $\sqrt{ }$ & $x$ & $\sqrt{ }$ & $\sqrt{ }$ & $\sqrt{ }$ & $x$ & $x$ & $x$ & & $x$ & $\sqrt{ }$ & $\sqrt{ }$ & $\sqrt{ }$ & $\sqrt{ }$ & $\sqrt{ }$ & 0.7 & 0.7 & 0.7 & 0.8 & 0.8 \\
\hline & $x$ & ${ }^{*}$ & $*$ & $x$ & $*$ & $x$ & * & $*$ & $x$ & $*$ & $x$ & $*$ & * & $x$ & * & $x$ & * & $*$ & $x$ & & $x$ & & * & $x$ & & $x$ & $*$ & * & $x$ & * & 0.0 & 0.0 & 0.0 & .0 & $*$ \\
\hline go & $x$ & $\sqrt{ }$ & * & $x$ & $x$ & $\sqrt{ }$ & $\sqrt{ }$ & $*$ & $x$ & $x$ & $x$ & $x$ & * & $x$ & $x$ & $\sqrt{ }$ & $\sqrt{ }$ & * & $x$ & $x$ & $x$ & $x$ & * & $x$ & $x$ & $x$ & $\sqrt{ }$ & * & $x$ & $x$ & 0.3 & 0.7 & 0.0 & 0.0 & 0.0 \\
\hline & $\sqrt{ }$ & $\sqrt{ }$ & $\sqrt{ }$ & $\sqrt{ }$ & $\sqrt{ }$ & $\sqrt{ }$ & $x$ & $\sqrt{ }$ & $\theta$ & $\sqrt{ }$ & $x$ & $x$ & $\times$ & $x$ & $x$ & $\sqrt{ }$ & $\sqrt{ }$ & $\sqrt{ }$ & $\sqrt{ }$ & $\sqrt{ }$ & $\times$ & & $x$ & $x$ & $\sqrt{ }$ & $x$ & $\sqrt{ }$ & $x$ & $x$ & $x$ & 5 & .5 & .5 & 4 & 0.4 \\
\hline & $\sqrt{ }$ & $\sqrt{ }$ & $\sqrt{ }$ & $\sqrt{ }$ & $\sqrt{ }$ & $\sqrt{ }$ & $x$ & $\sqrt{ }$ & $\sqrt{ }$ & $\sqrt{ }$ & $x$ & $x$ & $x$ & $x$ & $x$ & $\sqrt{ }$ & $\sqrt{ }$ & $\sqrt{ }$ & $\sqrt{ }$ & $\sqrt{ }$ & $\times$ & $x$ & $\sqrt{ }$ & $\sqrt{ }$ & $x$ & & $\sqrt{ }$ & $\sqrt{ }$ & $\sqrt{ }$ & $x$ & 5 & .5 & .8 & .8 & 0.8 \\
\hline & $\sqrt{ }$ & $\sqrt{ }$ & $\sqrt{ }$ & $\sqrt{ }$ & $\sqrt{ }$ & $\sqrt{ }$ & $\sqrt{ }$ & $\sqrt{ }$ & $\sqrt{ }$ & $\sqrt{ }$ & $\sqrt{ }$ & $x$ & $\sqrt{ }$ & $x$ & $\sqrt{ }$ & $\sqrt{ }$ & $\sqrt{ }$ & $\sqrt{ }$ & $\sqrt{ }$ & $\sqrt{ }$ & $x^{\prime}$ & $\sqrt{ }$ & $\sqrt{ }$ & $\sqrt{ }$ & $\sqrt{ }$ & & $\sqrt{ }$ & $\times$ & $\sqrt{ }$ & $x$ & .7 & 0.8 & & 8 & 0.8 \\
\hline Nay & $\sqrt{ }$ & $\sqrt{ }$ & $\sqrt{ }$ & $\sqrt{ }$ & $\sqrt{ }$ & $\sqrt{ }$ & $\sqrt{ }$ & $\sqrt{ }$ & $\sqrt{ }$ & $\sqrt{ }$ & $\sqrt{ }$ & $\sqrt{ }$ & $x$ & $\sqrt{ }$ & $\sqrt{ }$ & $\sqrt{ }$ & $\sqrt{ }$ & $\sqrt{ }$ & $\sqrt{ }$ & $\sqrt{ }$ & 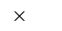 & & $\sqrt{ }$ & $\sqrt{ }$ & $x$ & & $\sqrt{ }$ & $\sqrt{ }$ & $\sqrt{ }$ & $x$ & 0.7 & 0.8 & 0.8 & .0 & 1.0 \\
\hline NL & $x$ & $\sqrt{ }$ & $\sqrt{ }$ & $\sqrt{ }$ & $\sqrt{ }$ & $\sqrt{ }$ & $\sqrt{ }$ & $\sqrt{ }$ & $\sqrt{ }$ & $\sqrt{ }$ & $x$ & $x$ & $\sqrt{ }$ & $\sqrt{ }$ & $\sqrt{ }$ & $\sqrt{ }$ & $\sqrt{ }$ & $\sqrt{ }$ & $\sqrt{ }$ & $\sqrt{ }$ & $x$ & $\sqrt{ }$ & $\sqrt{ }$ & $\sqrt{ }$ & $\sqrt{ }$ & $x$ & $\sqrt{ }$ & $\sqrt{ }$ & $\sqrt{ }$ & $\sqrt{ }$ & 0.3 & 0.8 & 1.0 & 1.0 & 1.0 \\
\hline Oax & $\sqrt{ }$ & $\sqrt{ }$ & $\sqrt{ }$ & $\sqrt{ }$ & $\sqrt{ }$ & $\sqrt{ }$ & $\sqrt{ }$ & $\sqrt{ }$ & $\sqrt{ }$ & $\sqrt{ }$ & $>$ & $x$ & $\sqrt{ }$ & $x$ & $\sqrt{ }$ & $\sqrt{ }$ & $\sqrt{ }$ & $\sqrt{ }$ & $\sqrt{ }$ & $\sqrt{ }$ & $x$ & $\sqrt{ }$ & $\sqrt{ }$ & $\sqrt{ }$ & $\sqrt{ }$ & $x$ & $\sqrt{ }$ & $\sqrt{ }$ & $\sqrt{ }$ & $\sqrt{ }$ & 0.5 & 0.8 & 1.0 & 0.8 & 0.8 \\
\hline Su & $\sqrt{ }$ & $\sqrt{ }$ & $\sqrt{ }$ & $\sqrt{ }$ & $\sqrt{ }$ & $\sqrt{ }$ & $\sqrt{ }$ & $\sqrt{ }$ & $\theta$ & $\sqrt{ }$ & $x$ & $x$ & $x$ & $x$ & $\sqrt{ }$ & $\sqrt{ }$ & $\sqrt{ }$ & $\sqrt{ }$ & $\sqrt{ }$ & $\sqrt{ }$ & $x$ & $\sqrt{ }$ & $x$ & $\sqrt{ }$ & $\sqrt{ }$ & $>$ & $\sqrt{ }$ & $\sqrt{ }$ & $\sqrt{ }$ & $x$ & 0.5 & 0.8 & 0.7 & 0.8 & 0.8 \\
\hline & $\sqrt{ }$ & $\sqrt{ }$ & $\sqrt{ }$ & $\sqrt{ }$ & $\sqrt{ }$ & $\sqrt{ }$ & $\sqrt{ }$ & $\sqrt{ }$ & $\sqrt{ }$ & $\sqrt{ }$ & $x$ & $x$ & $x$ & $\sqrt{ }$ & $\sqrt{ }$ & $\sqrt{ }$ & $\sqrt{ }$ & $\sqrt{ }$ & $\sqrt{ }$ & $\sqrt{ }$ & $x$ & $x$ & $\sqrt{ }$ & $\sqrt{ }$ & & & $x$ & $\sqrt{ }$ & $\sqrt{ }$ & $x$ & .5 & 0.5 & 0.8 & 1.0 & 1.0 \\
\hline & $\sqrt{ }$ & $\sqrt{ }$ & $\sqrt{ }$ & $\sqrt{ }$ & $\sqrt{ }$ & $\sqrt{ }$ & $x$ & $x$ & $\sqrt{ }$ & $\sqrt{ }$ & $\sqrt{ }$ & $\sqrt{ }$ & $\sqrt{ }$ & $\sqrt{ }$ & $\sqrt{ }$ & & & $x$ & $\sqrt{ }$ & $\sqrt{ }$ & $\sqrt{ }$ & $\sqrt{ }$ & $\sqrt{ }$ & $\sqrt{ }$ & $x$ & & $\sqrt{ }$ & $\sqrt{ }$ & $\sqrt{ }$ & $\sqrt{ }$ & & & & & .0 \\
\hline & $x$ & $\sqrt{ }$ & $\sqrt{ }$ & $\sqrt{ }$ & $\sqrt{ }$ & $\sqrt{ }$ & $x$ & $\sqrt{ }$ & $\sqrt{ }$ & $\sqrt{ }$ & $x$ & $x$ & $x$ & $x^{x}$ & $\sqrt{ }$ & $\sqrt{ }$ & 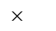 & $\sqrt{ }$ & $\sqrt{ }$ & $\sqrt{ }$ & & $\sqrt{ }$ & $\sqrt{ }$ & $\sqrt{ }$ & $\sqrt{ }$ & & $\sqrt{ }$ & $\sqrt{ }$ & $\sqrt{ }$ & $\sqrt{ }$ & 3 & 0.5 & 8 & 8 & 0.8 \\
\hline Sin & $\sqrt{ }$ & $\sqrt{ }$ & $\sqrt{ }$ & $\sqrt{ }$ & $\sqrt{ }$ & $\sqrt{ }$ & $\sqrt{ }$ & $\sqrt{ }$ & $\sqrt{ }$ & $\sqrt{ }$ & $x$ & $\times$ & $\sqrt{ }$ & $x$ & $x$ & $\sqrt{ }$ & $\sqrt{ }$ & $\sqrt{ }$ & $\sqrt{ }$ & $\sqrt{ }$ & $\times$ & $x$ & $\sqrt{ }$ & $x$ & $x$ & $x$ & $\sqrt{ }$ & $\sqrt{ }$ & $x$ & $x$ & 0.5 & 0.7 & 1.0 & 0.5 & 0.5 \\
\hline Son & $\sqrt{ }$ & $\sqrt{ }$ & $\sqrt{ }$ & $\sqrt{ }$ & $\sqrt{ }$ & $\sqrt{ }$ & $\sqrt{ }$ & $\sqrt{ }$ & $\sqrt{ }$ & $\sqrt{ }$ & $x$ & $x$ & $x$ & $x$ & $\sqrt{ }$ & $\sqrt{ }$ & $\sqrt{ }$ & $\sqrt{ }$ & $\theta$ & $\sqrt{ }$ & $x$ & $\sqrt{ }$ & $x$ & $x$ & $\sqrt{ }$ & $x$ & $\sqrt{ }$ & $x$ & $\sqrt{ }$ & $x$ & 0.5 & 0.8 & 0.5 & 0.6 & 0.6 \\
\hline Tab & $\sqrt{ }$ & $\sqrt{ }$ & $\sqrt{ }$ & $\sqrt{ }$ & $\sqrt{ }$ & $Q$ & $\sqrt{ }$ & $\sqrt{ }$ & $\theta$ & $\sqrt{ }$ & $\sqrt{ }$ & $\sqrt{ }$ & $\sqrt{ }$ & $x$ & $\sqrt{ }$ & $\theta$ & $\sqrt{ }$ & $\sqrt{ }$ & $\theta$ & $\sqrt{ }$ & $x$ & $\sqrt{ }$ & $\sqrt{ }$ & $\sqrt{ }$ & $x$ & $x$ & $\sqrt{ }$ & $\sqrt{ }$ & $\sqrt{ }$ & $x$ & 0.5 & 1.0 & 1.0 & 0.7 & 0.7 \\
\hline Гams & $x$ & $\sqrt{ }$ & $\sqrt{ }$ & $\sqrt{ }$ & $\sqrt{ }$ & $\times$ & $\sqrt{ }$ & $\sqrt{ }$ & $\theta$ & $\theta$ & $x$ & $x$ & $\sqrt{ }$ & $\sqrt{ }$ & $\sqrt{ }$ & $x$ & $\sqrt{ }$ & $\sqrt{ }$ & $\theta$ & $\theta$ & $x$ & & $x$ & $\sqrt{ }$ & 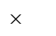 & & $\sqrt{ }$ & $x$ & $\sqrt{ }$ & $x$ & 0.0 & 0.7 & 0.7 & 0.8 & 0.8 \\
\hline & $\sqrt{ }$ & 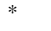 & $*$ & $\sqrt{ }$ & $\sqrt{ }$ & $\sqrt{ }$ & $*$ & $*$ & $\sqrt{ }$ & $\sqrt{ }$ & $x$ & * & $*$ & $\sqrt{ }$ & $\sqrt{ }$ & $\sqrt{ }$ & $*$ & $*$ & $\sqrt{ }$ & $\sqrt{ }$ & & & W & $x$ & $x$ & & . & * & $x$ & $x$ & 5 & .0 & & .7 & .7 \\
\hline & $x$ & $\sqrt{ }$ & $\sqrt{ }$ & $\sqrt{ }$ & $\sqrt{ }$ & $\sqrt{ }$ & $\sqrt{ }$ & & $\sqrt{ }$ & $\sqrt{ }$ & $\sqrt{ }$ & $\sqrt{ }$ & $\sqrt{ }$ & $\sqrt{ }$ & $\sqrt{ }$ & $\sqrt{ }$ & $\sqrt{ }$ & $\sqrt{ }$ & $\sqrt{ }$ & $\sqrt{ }$ & $x$ & $\sqrt{ }$ & $\sqrt{ }$ & $\sqrt{ }$ & $\sqrt{ }$ & & $\sqrt{ }$ & $\sqrt{ }$ & & $x$ & & .0 & & 8 & 0.8 \\
\hline & $\sqrt{ }$ & $\sqrt{ }$ & $\sqrt{ }$ & $\sqrt{ }$ & $\sqrt{ }$ & $\sqrt{ }$ & $\sqrt{ }$ & $\sqrt{ }$ & $\sqrt{ }$ & $\sqrt{ }$ & $\sqrt{ }$ & $x$ & $x$ & $\sqrt{ }$ & $\sqrt{ }$ & $\sqrt{ }$ & $\sqrt{ }$ & $\sqrt{ }$ & $\sqrt{ }$ & $\sqrt{ }$ & & $\sqrt{ }$ & $\sqrt{ }$ & ר & $\sqrt{ }$ & & $\sqrt{ }$ & $\sqrt{ }$ & $\sqrt{ }$ & & & 8 & 8 & 8 & .8 \\
\hline Zac & $\checkmark$ & $\sqrt{ }$ & $\sqrt{ }$ & $\sqrt{ }$ & $\sqrt{ }$ & $\sqrt{ }$ & $\sqrt{ }$ & $\sqrt{ }$ & $\sqrt{ }$ & $\sqrt{ }$ & $x$ & $x$ & $x$ & & $\sqrt{ }$ & $\sqrt{ }$ & $\sqrt{ }$ & $\sqrt{ }$ & $\sqrt{ }$ & $\sqrt{ }$ & $x$ & $\sqrt{ }$ & & & $\sqrt{ }$ & & $\sqrt{ }$ & & $x$ & $x$ & 0.5 & 0.8 & 0.5 & 0.5 & 0.5 \\
\hline Total & 25 & 23 & 29 & 29 & 29 & & 26 & 28 & 28 & 28 & 9 & 7 & 13 & 13 & 13 & & 26 & 27 & 21 & 27 & 4.5 & 3.5 & 15 & 15 & 15 & & & 19 & 19 & 19 & & & & & \\
\hline
\end{tabular}


Annex 5

Harmonization Index of accounts in accordance with IPSAS 1 and 2 (2008-2012).

\begin{tabular}{|c|c|c|c|c|c|c|c|c|c|c|}
\hline \multirow[t]{2}{*}{ State } & \multicolumn{2}{|l|}{2008} & \multicolumn{2}{|c|}{2009} & \multicolumn{2}{|c|}{2010} & \multicolumn{2}{|l|}{2011} & \multicolumn{2}{|c|}{2012} \\
\hline & $\begin{array}{l}\text { Requirements of } \\
\text { IPSAS } 1 \text { and } 2\end{array}$ & $p^{2}$ & $\begin{array}{l}\text { Requirements of } \\
\text { IPSAS } 1 \text { and } 2\end{array}$ & $p^{2}$ & $\begin{array}{l}\text { Requirements of } \\
\text { IPSAS } 1 \text { and } 2\end{array}$ & $p^{2}$ & $\begin{array}{l}\text { Requirements of } \\
\text { IPSAS } 1 \text { and } 2\end{array}$ & $p^{2}$ & $\begin{array}{l}\text { Requirements of } \\
\text { IPSAS } 1 \text { and } 2\end{array}$ & $p^{2}$ \\
\hline Ags & 19 & 0.00161 & 19 & 0.00161 & 21 & 0.00162 & 21 & 0.00156 & 17 & 0.00099 \\
\hline $\mathrm{BC}$ & 13 & 0.00144 & 13 & 0.00144 & 18 & 0.00119 & 3 & 0.00003 & 21 & 0.00151 \\
\hline BCS & 17 & 0.00084 & 17 & 0.00084 & 20 & 0.00147 & 21.5 & 0.00164 & 17 & 0.00099 \\
\hline Camp & 18 & 0.00012 & 18 & 0.00012 & 14 & 0.00072 & 15 & 0.0008 & 18 & 0.00111 \\
\hline Chis & 18 & 0.00127 & 18 & 0.00127 & 14 & 0.00072 & 22 & 0.00172 & 18 & 0.00111 \\
\hline Chih & 4 & 0.00008 & 4 & 0.00008 & 5 & 0.00009 & 6 & 0.00013 & 5 & 0.00009 \\
\hline Coah & 17 & 0.00006 & 17 & 0.00006 & 11 & 0.00044 & 4 & 0.00006 & 5 & 0.00009 \\
\hline $\mathrm{Col}$ & 15 & 0.00112 & 15 & 0.00112 & 16.5 & 0.001 & 20 & 0.00142 & 18 & 0.00111 \\
\hline DF & 21 & 0.00112 & 21 & 0.00112 & 16 & 0.00094 & 17 & 0.00102 & 18 & 0.00111 \\
\hline Dgo & 17 & 0.00161 & 17 & 0.00161 & 17 & 0.00106 & 16 & 0.00091 & 16 & 0.00088 \\
\hline Mex & 15 & 0.00127 & 15 & 0.00127 & 17 & 0.00106 & 16 & 0.00091 & 18 & 0.00111 \\
\hline Gto & 17 & 0.00161 & 17 & 0.00144 & 18 & 0.00119 & 21 & 0.00156 & 20 & 0.00137 \\
\hline Gro & 0 & 0.00008 & 0 & 0.00008 & 0 & 0 & 0 & 0 & 0 & 0 \\
\hline Hgo & 16 & 0.00012 & 16 & 0.00012 & 2 & 0.00001 & 3 & 0.00003 & 2 & 0.00001 \\
\hline Jal & 15 & 0.00112 & 15 & 0.00112 & 15 & 0.00083 & 15.5 & 0.00085 & 18 & 0.00111 \\
\hline Mich & 15 & 0.00127 & 15 & 0.00127 & 18 & 0.00119 & 17 & 0.00102 & 17.5 & 0.00105 \\
\hline Mor & 17 & 0.00144 & 17 & 0.00144 & 19 & 0.00132 & 18.5 & 0.00121 & 20 & 0.00137 \\
\hline Nay & 20 & 0.00179 & 20 & 0.00179 & 18 & 0.00119 & 20 & 0.00142 & 18 & 0.00111 \\
\hline NL & 18 & 0.00018 & 18 & 0.00018 & 20 & 0.00147 & 21 & 0.00156 & 21 & 0.00151 \\
\hline Oax & 15 & 0.00144 & 15 & 0.00144 & 17.5 & 0.00112 & 18.5 & 0.00121 & 22 & 0.00166 \\
\hline Pue & 18 & 0.00127 & 18 & 0.00127 & 19 & 0.00132 & 17.5 & 0.00109 & 19 & 0.00124 \\
\hline Qro & 15 & 0.00144 & 15 & 0.00144 & 18 & 0.00119 & 22 & 0.00172 & 17 & 0.00099 \\
\hline QRoo & 16 & 0.00127 & 16 & 0.00144 & 19 & 0.00132 & 20 & 0.00142 & 19 & 0.00124 \\
\hline SLP & 13 & 0.00072 & 13 & 0.00072 & 19 & 0.00132 & 21 & 0.00156 & 20 & 0.00137 \\
\hline Sin & 14 & 0.00097 & 14 & 0.00097 & 19 & 0.00132 & 17 & 0.00102 & 17 & 0.00099 \\
\hline Son & 19 & 0.00144 & 19 & 0.00144 & 18 & 0.00119 & 16.5 & 0.00097 & 17 & 0.00099 \\
\hline $\mathrm{Tab}$ & 18 & 0.00084 & 18 & 0.00084 & 18 & 0.00119 & 16 & 0.00091 & 18 & 0.00111 \\
\hline Tams & 17 & 0.00004 & 17 & 0.00004 & 18 & 0.00119 & 16 & 0.00091 & 16 & 0.00088 \\
\hline Tlax & 15 & 0.00097 & 15 & 0.00097 & 0 & 0 & 15 & 0.0008 & 14 & 0.00067 \\
\hline Ver & 19 & 0.00112 & 19 & 0.00112 & 21 & 0.00162 & 21 & 0.00156 & 17 & 0.00099 \\
\hline Yuc & 19 & 0.00161 & 19 & 0.00161 & 20 & 0.00147 & 19 & 0.00128 & 19 & 0.00124 \\
\hline $\mathrm{Zac}$ & 18 & 0.00144 & 18 & 0.00144 & 17 & 0.00106 & 14 & 0.0007 & 19 & 0.00124 \\
\hline Fed & 20 & 0.00179 & 20 & 0.00179 & 19 & 0.00132 & 20 & 0.00142 & 19 & 0.00124 \\
\hline Total & 528 & 0.03453 & 528 & 0.03452 & 522 & 0.03416 & 531 & 0.03442 & 540.5 & 0.03343 \\
\hline
\end{tabular}

Source: Own elaboration with federal and state public accounts. 


\section{References}

Araya, C., Caba, C., \& López, A. (2011). La innovación en los sistemas de información financiera gubernamental en la región centroamericana: Evidencias desde Costa Rica. INNOVAR, 21(41), 111-123.

Asociación Nacional de Organismos de Fiscalización Superior y Control Gubernamental. (2012). Manual de contabilidad gubernamental. México, DF: ANOFSCG.

Benito, B., Brusca, I., \& Montesinos, V. (2007). The harmonization of government financial information systems: The role of the IPSAS. International Review of Administrative Sciences, 73(2), 293-317.

Brusca, I., \& Montesinos, V. (2013). From rhetoric to practice: The case of Spanish local government reforms. Financial Accountability \& Management, 29(4), 354-377.

Chan, J. L. (2008). International public sector accounting standards: Conceptual and institutional issues [accessed 5 Jan 2015]. Available from: http://jameslchan.com/papers/Chan2008IPSAS3.pdf.

Chan, J. L., \& Zhang, Q. (2013). Government accounting standards and policies. In R. Allen, R. Hemming, \& B. Potter (Eds.), The International Handbook of Public Financial Management (pp. 742-766). Palgrave Macmillan UK.

Comisión Federal de Competencia. (1998). Resolución para el cálculo de los índices para determinar el grado de concentración en un mercado relevante y los criterios para su aplicación. En: Diario Oficial de la Federación. México: Comisión Federal de Competencia.

Consejo Nacional de Armonización Contable. (2012). Sistema gubernamental armonizado de información financiera [accessed 18 Feb 2013].. Available from: http://sigaif.mx/

Consejo Nacional de Armonización Contable. (2013). Informe anual de la armonización contable en México.. México, D.F. [accessed 16 Sep 2013]. Available from: http://www.conac.gob.mx/consejo.html

Ferreira, M. J. (2012). El uso del sistema integrado de administración financiera como instrumento de transparencia y control por la sociedad. Documento de debate del BID, 199, 1-56.

Fuertes, I. (2008). Towards harmonization or standardization in governmental accounting? The International Public Sector Accounting Standards Board Experience. Journal of Comparative Policy Analysis: Research and Practice, 10(4), 327-345

Galera, A. N., \& Bolívar, M. P. (2011). Utilidad del modelo de valoración de los IPSAS para la rendición de cuentas de los gobiernos: La perspectiva de los OCEX. Spanish Journal of Finance and Accounting/Revista Española de Financiación y Contabilidad, 40(149), 125-162.

González, P. (2011). Estudio empírico para medir aspectos de armonización entre las prácticas y normas contables utilizadas por las empresas argentinas, brasileñas y colombianas. Cuadernos de Administración, 21(34), 177.

International Federation of Accountants (IFAC) (2007). Manual of Standards Board Pronouncements of the International Public Sector Accounting. Nueva York, EUA [accessed 30 Jun 2010]. Available from: http://web.ifac.org/ publications/international-public-sector-accounting-standards-board/2007-handbook-spanish-ver \# 2007-handbookSpanish-ver

International Federation of Accountants (IFAC) (2013) [accessed 13 Feb 2014]. Available from: http://www.ifac.org/

Lara, M., Chávez, L., \& Toledo, I. (2011). La calidad de la información financiera presentada por Internet, en el marco de la armonización establecida en la ley de contabilidad gubernamental: Caso de las entidades federativas de México. Congreso Internacional de Investigación, I(8), 75.

Rhoades, S. A. (1993). Herfindahl-Hirschman index. Federal Reserve Bulletin, 188-189.

Rodríguez, C. P. (2009). Armonización contable, la experiencia chilena, un estudio sobre las partidas: Existencias, gastos de investigación y desarrollo, activo fijo e inversiones permanentes. In Congress Management Accounting in the New Context of International Accounting Standards. Chile: Universidad de Chile.

Sour, L. (2012). IPSAS and government accounting reform in Mexico. International Journal of Public Sector Performance Management, 2(1), 5-24.

Unidad de Contabilidad Gubernamental e Informes sobre la Gestión Pública (UCGIGP). (2008). Norma específica de información financiera gubernamental (NEIFG 004) valor de uso, depreciación-revaluación. México: Secretaría de Hacienda y Crédito Público. 